This is the Authors' preprint version of the paper:

Giancarlo Paganin, Adriana Angelotti, Chiara Ducoli, Monica Lavagna, Cinzia Talamo, Stefano Luccietto, Energy performance of an exhibition hall in a life cycle perspective: embodied energy, operational energy and retrofit strategies, Energy Efficiency 10:1343-1364 (2017).

The final publication is available at Springer via:

http://dx.doi.org/DOI 10.1007/s12053-017-9521-8 


\title{
Energy performance of an exhibition hall in a life cycle perspective: embodied energy, operational energy and retrofit strategies.
}

Giancarlo Paganin ${ }^{1}$, Adriana Angelotti ${ }^{2 *}$, Chiara Ducoli ${ }^{1}$, Monica Lavagna ${ }^{3}$, Cinzia Talamo ${ }^{3}$, Stefano Luccietto ${ }^{4}$

1 Department of Architecture and Urban Studies (DASTU), Politecnico di Milano, Milan, Italy

2 Department of Energy (DENG), Politecnico di Milano, Via Lambruschini 4, 20156 Milan, Italy

3 Department of Architecture, Built Environment and Construction Engineering (DABC), Politecnico di Milano, Milan, Italy

4 Fiera Milano SpA, Milan, Italy

* Corresponding author: adriana.angelotti@polimi.it

\section{Keywords}

Dynamic Energy Simulation, Life Cycle Energy Analysis, operational energy, embodied energy, energy retrofit, exhibition hall.

\begin{abstract}
Nowadays the focus on the buildings energy consumption in the use phase prevails over an interest concerning the energy impacts linked to all the other phases of the construction process. However, reducing operational energy could lead to shifting the impacts from one stage to another. Thus, combining the study of strategies improving energy efficiency in the use phase with a life cycle approach is crucial.

Exhibition halls are peculiar buildings from the geometry, construction and use point of view, rarely addressed in energy and Life Cycle Energy Analysis studies.

Therefore in this paper a representative hall of Milan Trade Fair is taken as a case study. A building energy simulation model is firstly calibrated in order to derive the operational energy for climatisation. The operational energy appears artificially low due the short use period during the year. When compared with the calculated embodied energy of the envelope and structure, it is found that 57 years would be needed to balance energy spent in the construction and in the use phase.

Further, some retrofit interventions are proposed and analyzed. Insulation interventions are not attractive from the Economic PayBack Time point of view. However, when the embodied energy of the retrofit interventions is compared with the energy savings in the use phase, interesting Energy PayBack Times are obtained. Therefore this study puts in evidence the importance of adopting a life cycle perspective, especially for buildings with a low-intensity use. Eventually the critical issues of the Life Cycle Energy Analysis are deeply discussed.
\end{abstract}




\section{Introduction}

Several studies in literature have shown that in traditional buildings the energy consumption during the use phase (for heating and cooling) was so relevant that in a few years it exceeded the energy spent for the building construction. However, since the new mandatory regulations on energy saving encourage low-energy buildings, the construction phase has acquired a growing role (Weissenberger et al. 2014; Stephan et al. 2013). Life Cycle Energy Assessment (LCEA) evaluates the energy use as a resources input to a building over the total life cycle (Chau et al. 2015). From a review of LCEA of 73 cases (both residential and office buildings, in 13 countries), Ramesh et al. (2010) found that the embodied energy accounts on average for $10-20 \%$ of the total life cycle energy demand, except in cases of energy-efficient buildings: low energy buildings perform better than Zero (operational) Energy Buildings in the total life cycle energy balance due to the lower embodied energy, namely the excessive use of passive and active features may be counterproductive. Rossellò-Batle et al. (2015) investigated the relationship between initial embodied energy and energy demands in dwellings in a Mediterranean climate, focusing especially on changes in facades, roofing systems and window frames and on thermal bridges insulation. The found that using polyurethane or extruded polystyrene in facades, and replacing timber by lacquered aluminum in window frames, provides an increase of the primary initial embodied energy equivalent to the final heating energy requirements of a detached house for more than 5 and 10 years respectively. In turn, insulating thermal bridges causes a very modest increase in the primary initial embodied energy. Crawford et al. (2016) used a case study house in Australia to investigate the life cycle primary energy repercussions of increasing building energy efficiency levels over 50 years. They show that the point at which supplementary insulation materials do not yield life cycle energy benefits is just above current minimum energy efficiency requirements in Australia.

Starting from these considerations, the embodied energy calculation can help to achieve an optimized energy balance, comparing the energy saving in the use phase with the energy spent to realize a low-energy building.

Official statistics (ENEA 2013) support the need for energy saving policies that incorporate the life cycle approach. In fact, the buildings sector in Italy roughly corresponds to $36 \%$ of the final energy use (in Europe it corresponds to $41 \%$ ), but when the manufacturing of construction materials (cement, bricks, glass, ceramics, etc.) is included and building activities are considered, the final energy use and greenhouse emissions rise over $50 \%$.

From the voluntary point of view, environmental building rating systems (e.g. LEED, BREEAM, DGNB) focus mainly on operational impacts and are only starting to include embodied impacts of the building (Anderson et al. 2015). For instance, some limits of current Green Rating Systems are shown by Lee et al. (2011), who compared different building materials (concrete vs steel) for the structure of an industrial hall. They found that a significant improvement in material choice and embodied energy for the industrial hall is not adequately reflected under the material category of the LEED system.

From the regulation point of view, the need for more comprehensive energy codes for the building sector, able to combine embodied and operational energy, is stated by several authors (Crawford et al. 2016, Szalay 2007, Dodoo et al. 2011).

In the scientific literature, many studies deal with the issue of reducing energy consumption in the use phase through the use of simulation tools (Li et al. 2014; Crawley et al. 2001; Fumo et al. 2010; Boyano et al. 2013; Kim and Park 2011), also focusing on the model calibration to ensure the 
accuracy of the model itself (Ryan and Sanquist 2012; Heo et al. 2011; Raftery et al. 2011a; Raftery et al. 2011b; Nassiopoulosa et al. 2014; Mustafaraj et al. 2014). But the interest in reducing energy consumption during the use phase may lead to shift impacts from one phase to another and from one kind of impact to another, simply by redistributing the total load (Sartori et al. 2007; Blengini and Di Carlo 2010; Gustavsson and Joelsson 2010). Thus the information extracted from a Life Cycle Energy Analysis can make the designers aware of the impacts of the whole life cycle related to the design choices and can support them in their decision making.

Most studies performing energy analyses in a life cycle perspective deal either with residential or commercial buildings (Sartori et al. 2007; Blengini and Di Carlo 2010; Gustavsson and Joelsson 2010; Buyle et al. 2013; Sharma et al. 2011; Cabeza et al. 2014; Atmaca and Atmaca 2015; Din and Brotas 2016; Stephan and Stephan 2014). Among the latter however, buildings dedicated to exhibitions are rarely addressed. This kind of buildings presents peculiar features. From the energy modeling point of view, trade fair buildings are usually large single volumes with considerable height possibly leading to thermal stratifications and are characterized by high internal loads due to the relevant number of users and amount of electric equipment installed. From the life cycle point of view, their use during the year is often discontinuous and low-intensity, possibly leading to low yearly operational energy figures; in the construction prefabricated components are often adopted; finally, being a large single volume with a few internal partitions and slabs, the quantity of construction materials per unit floor area is expected to be less than in other kinds of buildings. These features make the use phase and embodied energy analysis of such buildings worthy of investigation. Further, a question arises on the advisability for such buildings of retrofit interventions aiming at reducing operational energy. It can be remarked that some features of the exhibition halls listed above might be found in other kinds of buildings, such as industrial halls (the large internal volume with unobstructed spans) and buildings devoted to entertainment (the lowintensity use), and therefore analyzing exhibition halls can provide outcome partially applicable also in such cases.

Starting from these considerations, this paper presents an energy analysis with a life cycle perspective of an exhibition hall. The case study is a sample hall in the Milan Trade Fair. The analysis focuses at first on the present energy performance of the hall, described in terms of both operational and embodied energy. Secondly, retrofit interventions are proposed and investigated. An economic and energy costs-benefits assessment related to the achievable energy savings of retrofit interventions is carried out. Finally, a discussion on the critical issues related to the performed Life Cycle Energy Analysis is presented.

\section{Case study}

As it was mentioned above, the case study presented in this paper is the Milan Trade Fair, whose new premises were inaugurated in 2005.

The complex consists of 8 buildings, divided into 20 pavilions. 6 of them are one-storey buildings ( $164.5 \mathrm{~m} \times 224.31 \mathrm{~m}$ and clear height $13 \mathrm{~m}$ ) and 2 of them are two-storey buildings, for a total of $345,000 \mathrm{~m}^{2}$ and $60,000 \mathrm{~m}^{2}$ of gross exhibition space outdoor.

In this analysis, a representative hall will be considered, namely the 5-7 (Figure 1). The results of the energy analysis on the sample hall could be subsequently transferred to the other halls. 


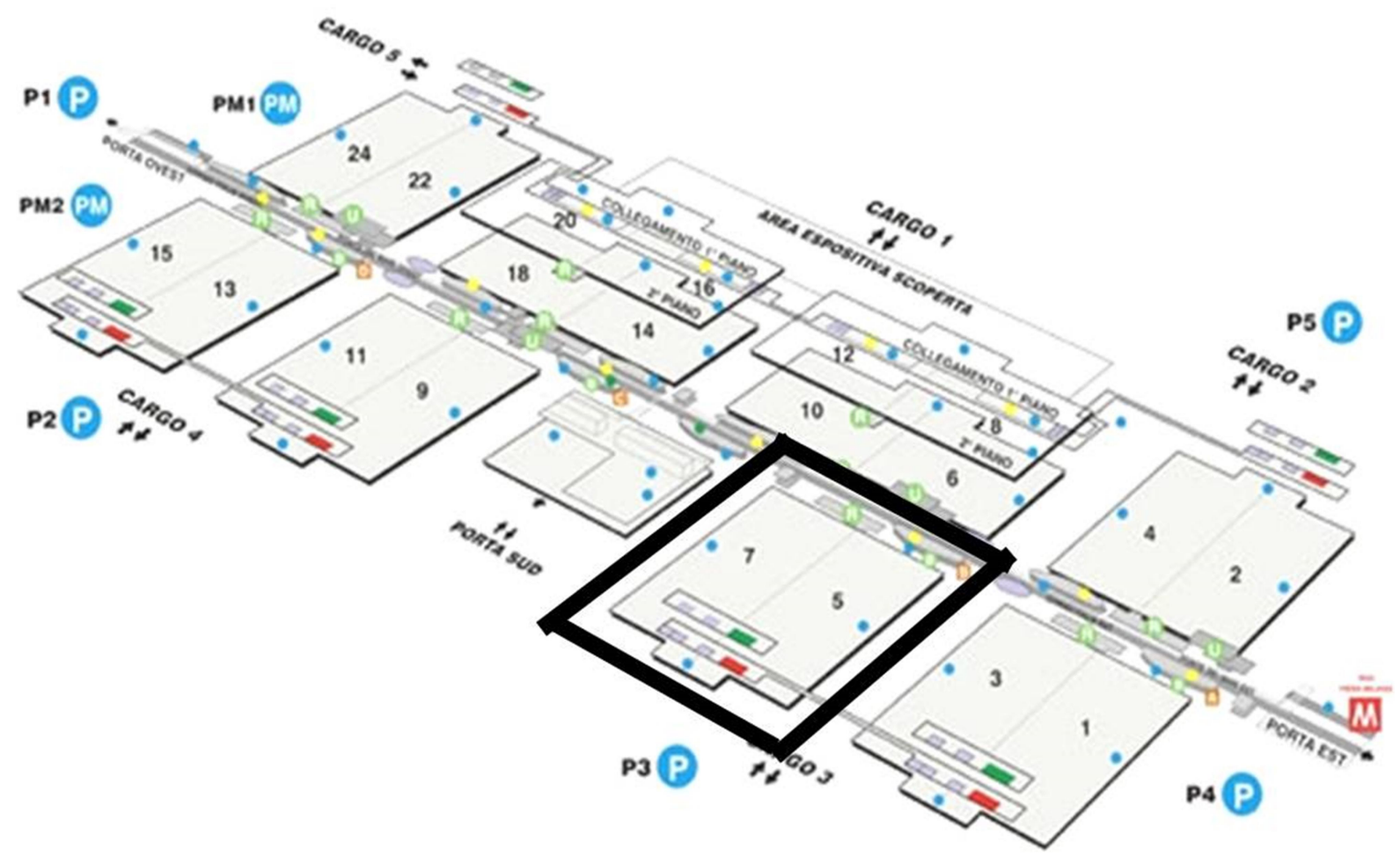

Figure 1. The Milan Trade Fair layout and the sample hall 5-7 marked in black.

Considering a representative year, throughout the exhibition center it is possible to estimate about 70 events. The monitoring system of the trade fair measures the cooling and heating energy provided to the Air Handling Unit (AHU) of each hall, in terms of delivered cold/hot water, as well as the electricity consumption of the hall for lighting and appliances. In Table 1, for each event that took place in 2009 in the sample hall, the measured delivered energy for cooling and heating and the electric consumption for lighting and appliances are shown, as well as the recorder number of guests.

Table 1. Events calendar of the typical hall during 2009 and corresponding measured data.

\begin{tabular}{cccccc}
\hline & & $\begin{array}{c}\text { Delivered } \\
\text { cooling energy }\end{array}$ & $\begin{array}{c}\text { Delivered } \\
\text { heating energy }\end{array}$ & $\begin{array}{c}\text { Electric } \\
\text { consumption } \\
\text { (lighting and } \\
\text { appliances) }\end{array}$ & $\begin{array}{c}\text { Number of } \\
\text { guests }\end{array}$ \\
\cline { 3 - 6 } & Period & $\mathrm{kWh}$ & $\mathrm{kWh}$ & $\mathrm{kWh}$ & - \\
\hline 1 & $16 / 01$ to $19 / 01$ & - & 99,473 & 97,860 & 3,462 \\
\hline 2 & $04 / 02$ to $07 / 02$ & - & 68,125 & 84,757 & 6,927 \\
\hline 3 & $19 / 02$ to $22 / 02$ & - & 90,675 & 73,997 & 6,667 \\
\hline 4 & $04 / 03$ to $07 / 03$ & - & 58,610 & 95,914 & 2,813 \\
\hline 5 & $24 / 03$ to $28 / 03$ & - & 35,189 & 102,867 & 8,571 \\
\hline 6 & $22 / 04$ to $27 / 04$ & 60,443 & - & 158,744 & 22,143 \\
\hline
\end{tabular}




\begin{tabular}{cccccc}
\hline 7 & $04 / 09$ to $07 / 09$ & 112,275 & - & 54,612 & 3,000 \\
\hline 8 & $16 / 09$ to $19 / 09$ & 90,542 & - & 91,542 & 2,813 \\
\hline 9 & $05 / 10$ to $10 / 10$ & 165,308 & - & 177,249 & 6,061 \\
\hline 10 & $23 / 10$ to $27 / 10$ & 18,738 & - & 98,229 & 4,364 \\
\hline 11 & $06 / 12$ to $12 / 12$ & - & 107,004 & 198,984 & 27,778 \\
\hline
\end{tabular}

\section{Methodology}

In this research, the present energy performance of a representative hall in the Milan Trade Fair was analyzed by means of dynamic simulations performed in EnergyPlus (2009) on a calibrated model of the case study building. Then the embodied energy of the hall was calculated and compared on the one side with the embodied energy of other kinds of buildings, and on the other side with the operational energy achieved by means of dynamic energy simulation.

The simulation model was then used to evaluate the effects of some energy saving interventions. Then an Economic PayBack Time assessment was carried out. After that, the energy impacts of the retrofit strategies during the life cycle were assessed and compared with the energy savings in the use phase, allowing to calculate the Energy PayBack Time.

To summarise, the research involved the following steps:

- simulation model setup and model calibration: a representative exhibition hall was chosen; all the geometrical and thermal-physical characteristics were elaborated in the software DesignBuilder (2009) to develop a 3D model; the model was then imported in EnergyPlus where the additional inputs regarding the Heating, Ventilating and Air Conditioning (HVAC) system and the hall use were provided. A representative event in winter and another in summer were chosen to compare the energy consumption obtained from the dynamic simulations with the measured data (Table 1) and then to tune the model. Then the calibrated model was used to derive the end-use operational energy for heating and cooling on a typical year and, by considering the systems efficiency, the corresponding primary energy.

- Calculation of the embodied energy of the hall and comparison between the energy spent for the construction of the building and the operational energy. For the embodied energy calculation envelope and structure were taken into account, while technical building services were not included. The Life Cycle Energy Analysis was performed according to the ISO-complying process-based methodology.

- Study of energy saving strategies: an annual dynamic simulation with typical weather data and usage pattern from a typical year was performed and dynamic annual energy simulations of different interventions (at the envelope and system management levels) were carried out.

- The economic assessment of the cost-benefit related to the interventions, through the calculation of the Economic PayBack Time (simple and discounted), together with the Net Present Value and the Internal Rate of Return, was carried out.

- The assessment of the energy impacts of retrofit strategies in the life cycle (the embodied energy and the energy due to the transport of the materials to the building site) and the 
comparison with the related energy savings in the use phase, checking the Energy PayBack Time, were carried out.

- A discussion on the critical issues of the Life Cycle Energy Analysis performed is proposed.

\section{Simulation model and operational energy calculation}

\subsection{Model set up and calibration}

The first step of this analysis is the construction of the 3D model of the building processed in DesignBuilder with the thermal physical description of the envelope (Figure 2). Thermal-physical properties of the envelope materials came from UNI 10351 (1994). Thermal bridges were calculated according to UNI EN ISO 14683 (2001) but their effect was found to be negligible. The DesignBuilder model was then entered in EnergyPlus to elaborate the simulation model.

A single thermal zone was adopted, since spot measurements in the exhibition hall in different horizontal and vertical positions resulted in a maximum temperature difference equal to $2{ }^{\circ} \mathrm{C}$, and therefore the well mixed volume assumption appeared a reasonable approximation.
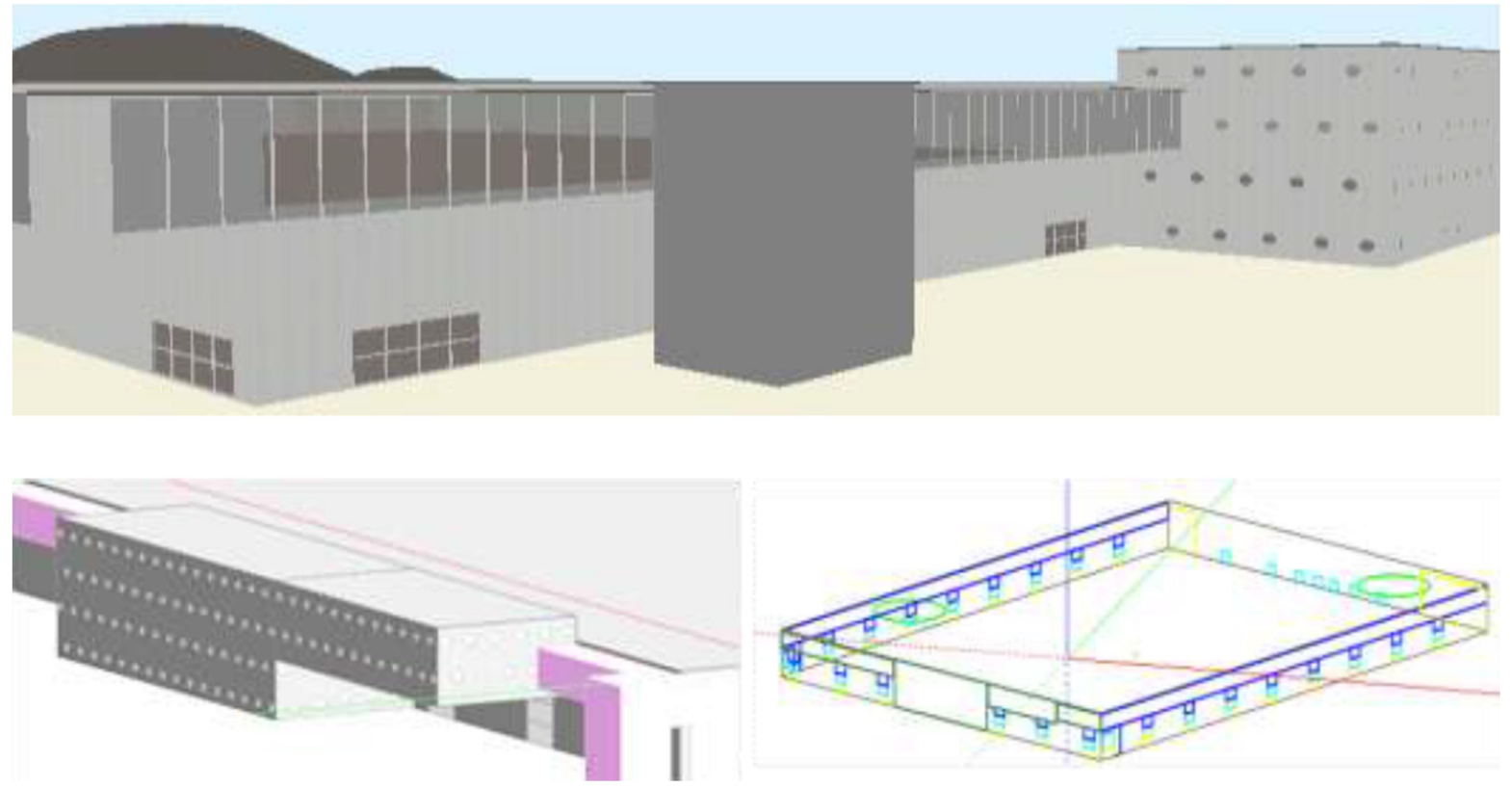

Figure 2. The simplified 3D model of the sample hall.

The model was calibrated during a representative exhibition in winter and in summer, comparing the results of the dynamic simulation with the measured delivered heating/cooling energy. In order to calibrate the winter and summer events, the following input data were entered in EnergyPlus:

- geometry and thermal zone (using the 3D model just developed);

- operating schedule of the hall in an hourly step (the operating schedule of the AHU, the set point temperature, etc.);

- internal load schedules (people distribution and electric equipment); 
- Air Changes per Hour (ACH) due to natural infiltration and ventilation;

- weather file based on 2009 data measured at Milan Trade Fair site (as far as dry bulb temperature and humidity are concerned) and at a nearby weather station (for the rest of the data).

The results of the calibration are reported in Figure 3 in terms of comparison between measured and simulated heating or cooling rate.
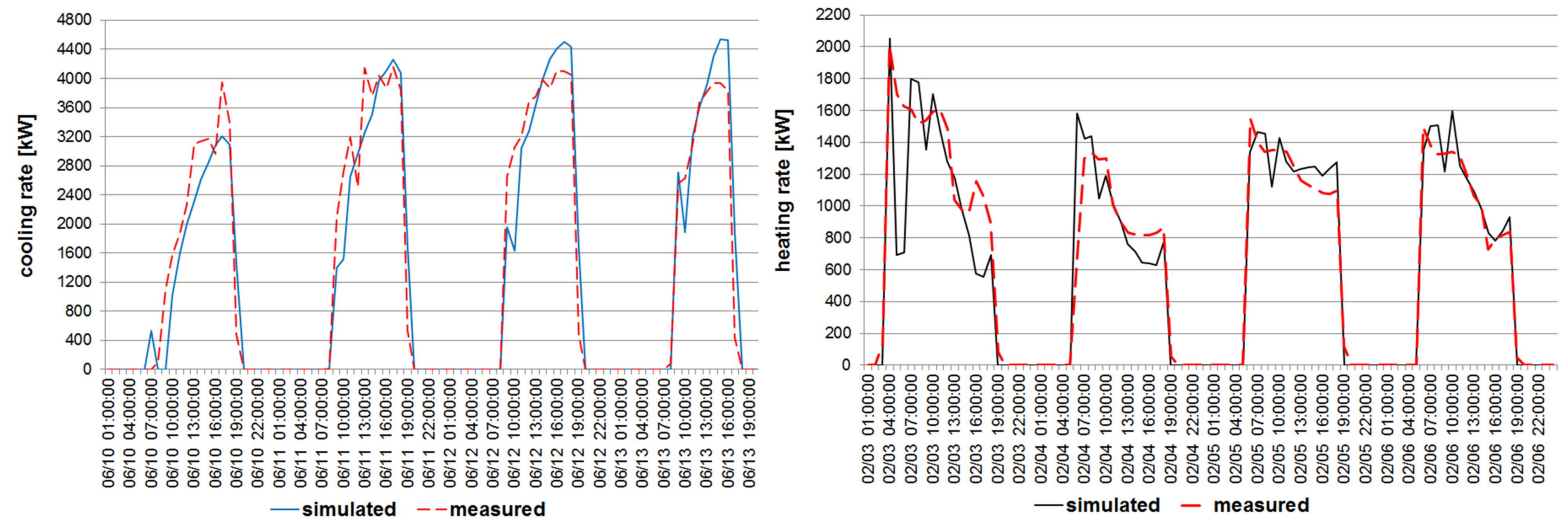

Figure 3. Measured and simulated cooling and heating rate during the representative event in summer (left) and winter (right).

The calibration parameters chosen were the $\mathrm{ACH}$ and the occupants distribution during the day. In fact, since the AHU was not included in the model but measured consumption refers to the AHU level, the ACH in the simulation model represent the sum of the infiltration air changes of the envelope and the ventilation air changes handled by the real system. The monitoring system of the trade fair does not measure the proportion of indoor/outdoor air flow rates handled by the system. However it is known that the ventilation flow rates range between a minimum of $0.4 \mathrm{vol} / \mathrm{h}$ and a maximum of $2 \mathrm{vol} / \mathrm{h}$.

The calibration led to variable $\mathrm{ACH}$ during the day, in order to take into account the on/off of the mechanical ventilation system and the effects of the visitors presence. Therefore the ACH were set at $0.1 \mathrm{vol} / \mathrm{h}$ during the night both in winter and summer, at $0.9 \mathrm{vol} / \mathrm{h}$ in the visiting hours of the day in winter and at $1.4 \mathrm{vol} / \mathrm{h}$ in the visiting hours of the day in summer. 3 hours before the start of the events, half of the diurnal $\mathrm{ACH}$ were set, because of the presence of the stand fitters.

The other calibration parameter is the people distribution during the day. From the measured total number of visitors in a day, two profiles were created. One profile was derived assuming that all the visitors recorded in a day are in the hall during the central hours, while $1 / 3$ of the total is assumed to be there in the opening and closing hours. Instead a second profile was derived assuming that the sum of the people present every hour is equal to the total daily number of visitors. Therefore in the winter representative event a larger number of people decreases the heating rate, because it means a higher internal load. The opposite is found in the summer event. However the kind of people distribution seems to be more important in winter than in summer. This could be understood also considering that, during the winter event, internal loads due to the people and to the electric equipment are similar, while during the summer event, internal loads due to the people are about $1 / 3$ 
of the electric loads. In the calibration, the people distribution corresponding to the first profile was chosen for a better match with measured data.

In the end of the calibration process, the differences between the measured and the simulated overall energy were $4.2 \%$ for the winter event and $2.7 \%$ for the summer one.

\subsection{Operational energy calculation}

After calibrating the model, a dynamic simulation of a representative year was performed, using typical meteorological year weather data for Milan. Since available energy consumption data refer to a specific year, namely 2009 , this simulation allowed to derive the yearly operational energy for heating and cooling in terms of end-use energy for a typical year. The main characteristics of the hall model adopted in the yearly simulation are summarized in Table 2.

The heating demand of the Milan Trade Fair is covered at $95 \%$ by the Waste-To-Heat municipality district heating system, with a thermal efficiency including district network losses equal to $33 \%$, and at $5 \%$ by backup gas boilers, with an efficiency equal to $85 \%$. The cooling demand is satisfied by centrifugal chillers coupled with cooling towers, for which a $\mathrm{COP}=6$ was assumed. By taking into account the national electrical efficiency equal to 41\% (Decree 2015/06/26), the yearly operational energy of the sample hall in terms of primary energy was obtained. It was found that the total operational primary energy consumed by the hall (renewable and non-renewable) is equal to $27.80 \mathrm{kWh} /\left(\mathrm{m}^{2} . \mathrm{a}\right)$ or $100.06 \mathrm{MJ} /\left(\mathrm{m}^{2} . \mathrm{a}\right)$, where the gross floor area was taken into account to normalize the energy consumption. Such low figures should not be intended to mean the hall is a low-energy building with a particularly high-performance envelope, being rather the consequence of the small use period of the hall during the year, equal to only 52 days. Indeed, by normalizing over the effective use period during the year, the total operational primary energy of the hall becomes $195.13 \mathrm{kWh} /\left(\mathrm{m}^{2} . \mathrm{a}_{\mathrm{eff}}\right)$.

Table 2. Main characteristics of the hall model adopted for the yearly simulation of the operational energy.

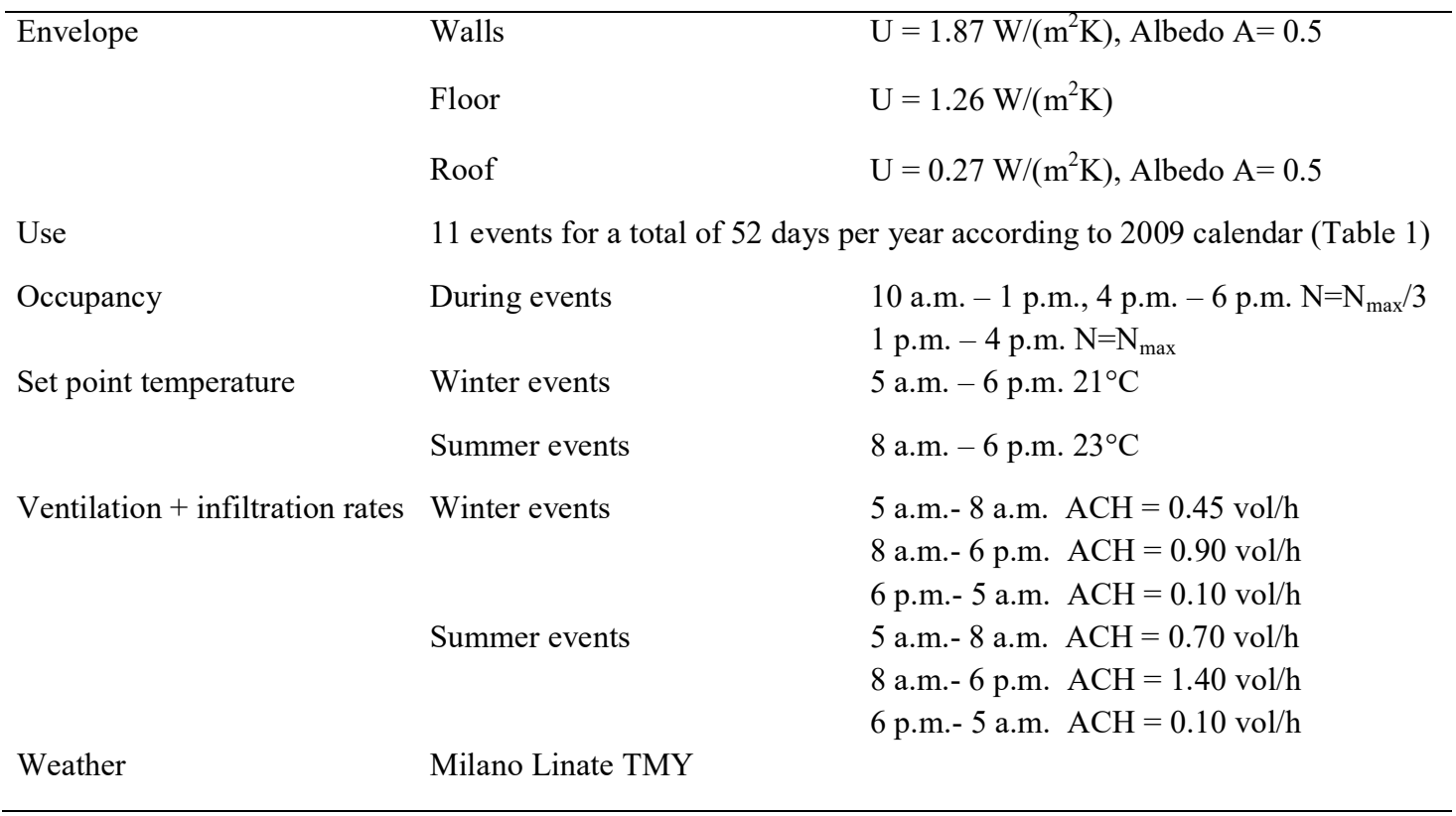




\section{Calculation of the embodied energy of the hall}

After calculating the operational energy of the sample hall, the embodied energy of the envelope and structure of the hall has been estimated (Table 3). The values of embodied energy "from cradle to gate" from the Inventory of Carbon and Energy (Hammond and Jones 2011) were used.

Table 3. Bill of materials quantities of the hall and embodied energy coefficients.

\begin{tabular}{|c|c|c|c|c|c|c|c|}
\hline \multirow[t]{2}{*}{ Part of the hall } & \multirow[t]{2}{*}{ Material } & Thickness & Area & Density & Weight & $\begin{array}{c}\text { Embodied } \\
\text { Energy coeff. }\end{array}$ & $\begin{array}{l}\text { Embodied } \\
\text { Energy }\end{array}$ \\
\hline & & $\mathrm{m}$ & $\mathrm{m}^{2}$ & $\mathrm{~kg} / \mathrm{m}^{3}$ & $\mathrm{~kg}$ & $\mathrm{MJ} / \mathrm{kg}$ & MJ \\
\hline Structure & steel & - & - & 7,800 & $3,500,000$ & 20.1 & $70,350,000$ \\
\hline \multirow{2}{*}{$\begin{array}{l}\text { Foundation } \\
\text { structure }\end{array}$} & gravel & 0.35 & \multirow{2}{*}{37,242} & 1,950 & $25,417,665$ & 0.08 & $2,109,666$ \\
\hline & concrete & 0.3 & & 1,800 & $20,110,680$ & 0.99 & $19,909,573$ \\
\hline \multirow{3}{*}{ Concrete panel } & concrete & 0.05 & \multirow{3}{*}{3,707} & 2,000 & 370,700 & 0.75 & 278,025 \\
\hline & polystyrene & 0.14 & & 30 & 15,569 & 86.4 & $1,345,196$ \\
\hline & concrete & 0.06 & & 2,000 & 444,840 & 0.75 & 333,630 \\
\hline \multirow{3}{*}{ Steel panel } & Steel sheet & 0.0005 & \multirow{3}{*}{2,454} & 7,800 & 9,571 & 20.1 & 192,369 \\
\hline & $\begin{array}{l}\text { Polyurethane } \\
\text { foam }\end{array}$ & 0.08 & & 35 & 6,785 & 102.1 & 692,780 \\
\hline & $\begin{array}{c}\text { Corrugated } \\
\text { aluminium sheet }\end{array}$ & 0.0005 & & 2,700 & 3,313 & 155 & 513,500 \\
\hline \multirow{3}{*}{$\begin{array}{l}\text { Aluminium } \\
\text { panel }\end{array}$} & Aluminium sheet & 0.0025 & \multirow{3}{*}{3,112} & 2,700 & 21,003 & 155 & $3,255,501$ \\
\hline & Rock wool & 0.12 & & 120 & 44,807 & 16.8 & 752,756 \\
\hline & Plasterboard & 0.0125 & & 900 & 35,005 & 6.75 & 236,286 \\
\hline Floor & $\begin{array}{c}\text { Precast } \\
\text { reinforced } \\
\text { concrete slab }\end{array}$ & 0.2 & 37,242 & 2,400 & $17,876,160$ & 4.5 & $80,442,720$ \\
\hline \multirow{5}{*}{$\begin{array}{l}\text { Floor Service } \\
\text { Building }\end{array}$} & Ceramic & 0.02 & \multirow{5}{*}{559} & 2,300 & 25,714 & 10.0 & 257,140 \\
\hline & Concrete & 0.08 & & 1,800 & 80,496 & 1.33 & 107,060 \\
\hline & $\begin{array}{l}\text { Lightweight } \\
\text { concrete }\end{array}$ & 0.06 & & 500 & 16,770 & 1.33 & 22,304 \\
\hline & $\begin{array}{c}\text { Precast } \\
\text { reinforced } \\
\text { concrete slab }\end{array}$ & 0.14 & & 2,300 & 179,998 & 4.5 & 809,991 \\
\hline & $\begin{array}{c}\text { Corrugated steel } \\
\text { sheet }\end{array}$ & 0.001 & & 7,800 & 4,360 & 20.1 & 87,640 \\
\hline \multirow{4}{*}{ Roof } & $\begin{array}{l}\text { Aluminium } \\
\text { coating }\end{array}$ & 0.0009 & \multirow{4}{*}{35,015} & 2,700 & 85,087 & 155 & $13,188,475$ \\
\hline & Glass wool & 0.14 & & 14 & 68,629 & 28 & $1,921,634$ \\
\hline & $\begin{array}{c}\text { Corrugated steel } \\
\text { sheet }\end{array}$ & 0.001 & & 7,800 & 273,117 & 20.1 & $5,489,683$ \\
\hline & Mineral wool & 0.02 & & 150 & 105,045 & 16.6 & $1,743,757$ \\
\hline \multirow{2}{*}{$\begin{array}{l}\text { Roof Service } \\
\text { Building }\end{array}$} & Aluminium sheet & 0.0009 & \multirow{2}{*}{1,317} & 2,700 & 3,200 & 155 & 495,973 \\
\hline & Glass wool & 0.04 & & 40 & 2,107 & 28.0 & 58,993 \\
\hline
\end{tabular}




\begin{tabular}{|c|c|c|c|c|c|c|c|}
\hline & Concrete & 0.05 & & 1,600 & 105,344 & 1.33 & 140,108 \\
\hline & $\begin{array}{c}\text { Precast } \\
\text { reinforced } \\
\text { concrete slab }\end{array}$ & 0.13 & & 2,400 & 410,842 & 4.5 & $1,848,787$ \\
\hline & $\begin{array}{c}\text { Precast } \\
\text { reinforced } \\
\text { concrete }\end{array}$ & 0.13 & & 2,300 & 393,723 & 4.5 & $1,771,754$ \\
\hline & $\begin{array}{c}\text { Corrugated steel } \\
\text { sheet }\end{array}$ & 0.001 & & 7,800 & 10,272 & 20.1 & 206,448 \\
\hline Glass & Glass & 0.016 & 1,436 & 2,400 & 55,142 & 15 & 827,136 \\
\hline Frame & Aluminium & 0.05 & 218 & 2,700 & 29,430 & 155 & $4,561,650$ \\
\hline
\end{tabular}

The total embodied energy is the compared with the yearly operational energy of the hall Table 4, where figures are also normalized by the area $\left(37,240 \mathrm{~m}^{2}\right)$ and by the volume $\left(497,530 \mathrm{~m}^{3}\right)$. Considering the total embodied and operational energy during 50 years, the embodied energy is quite similar to the operational energy.

Table 4. The total embodied and the total operational energy of the hall.

\begin{tabular}{lll} 
Embodied energy & $\begin{array}{l}\text { Operational energy } \\
(1 \text { year })\end{array}$ & $\begin{array}{l}\text { Operational energy } \\
(50 \text { years })\end{array}$ \\
\hline $213,950 \mathrm{GJ}$ & $3,727 \mathrm{GJ} / \mathrm{a}$ & $186,350 \mathrm{GJ}$ \\
\hline $5,745 \mathrm{MJ} / \mathrm{m}^{2}$ & $100 \mathrm{MJ} /\left(\mathrm{m}^{2} \cdot \mathrm{a}\right)$ & $5,000 \mathrm{MJ} / \mathrm{m}^{2}$ \\
\hline $430 \mathrm{MJ} / \mathrm{m}^{3}$ & $7.5 \mathrm{MJ} /\left(\mathrm{m}^{3} \cdot \mathrm{a}\right)$ & $375 \mathrm{MJ} / \mathrm{m}^{3}$ \\
\hline
\end{tabular}

In order to compare the total embodied energy of the hall with the one of other buildings types, some reference values were found in environmental certification systems: $2.6 \mathrm{GJ} / \mathrm{m}^{2}$ is the reference value for the embodied energy of the envelope and structure of Italian residential buildings, related to Protocollo ITACA (ITC-CNR 2009); $120 \mathrm{MJ} /\left(\mathrm{m}^{2} . \mathrm{a}\right)$ is the reference value for the embodied energy of the whole building (equipment included), related to DGNB (Deutsches Gütesiegel Nachhaltiges Bauen), the German Green Building Rating System (Ganassali et al. 2013); 150 $\mathrm{MJ} /\left(\mathrm{m}^{2} . \mathrm{a}\right)$ is the limit value for the embodied energy of the whole building (equipment included) for school, office and residential buildings, related to Minergie-ECO, the Swiss environmental certification system (Ganassali et al. 2013).

The first value $\left(2.6 \mathrm{GJ} / \mathrm{m}^{2}\right.$, related to ITACA) has to be compared with $5.7 \mathrm{GJ} / \mathrm{m}^{2}$ of the exhibition building under study. At a first glance, it seems that the embodied energy of the hall is more than two times the residential building one (ITACA). However, considering the significant internal height of the hall $(13.36 \mathrm{~m})$, it seems worth to compare the values per unit volume: the embodied energy of the residential building is then $0.87 \mathrm{GJ} / \mathrm{m}^{3}$ (considering $3 \mathrm{~m}$ of floor height) and the exhibition building one is $0.43 \mathrm{GJ} / \mathrm{m}^{3}$. It has to be remarked that due to the uniqueness of the considered typology (a large hall with unobstructed spans and with few slabs and partitions), the trade fair sample hall is actually not comparable with a residential building. Indeed the objective of this study is also to define a reference value (benchmark) for this building typology, considering the lack of similar case studies in literature.

The other two values $\left(120 \mathrm{MJ} /\left(\mathrm{m}^{2} . \mathrm{a}\right)\right.$, related to $\mathrm{DGNB}$, and $150 \mathrm{MJ} /\left(\mathrm{m}^{2} . \mathrm{a}\right)$, related to MinergieECO, have to be compared with $115 \mathrm{MJ} /\left(\mathrm{m}^{2}\right.$.a), considering a use phase of 50 year (as provided in 
the DGNB and Minergie certification). In these cases, the hall embodied energy seems lower, but it has to be reminded that it takes into account only the envelope and the structures, namely equipment is excluded.

After calculating the embodied energy of the hall, it seemed reasonable to compare it with the operational energy to see the relationship between the energy spent for the construction of the building and the energy used during the useful life of the building (Errore. L'origine riferimento non è stata trovata.).

In Figure 4 the embodied energy, reported at the first year of operation of the hall, and the increasing operational energy at different years are shown. Figure 4 shows that a little more than 57 years are needed before the energy consumption in the use phase balances the embodied energy. However, it has to be noted that these 57 years are not fully exploited, because, as already mentioned, the hall is used only 52 days per year. If the hall were used 365 days per year, in less than 8 years the embodied energy would equalize the operational energy. It has to be remarked that continuous operation would likely result in a lower daily consumption, since the envelope thermal inertia would help reducing the peak loads.

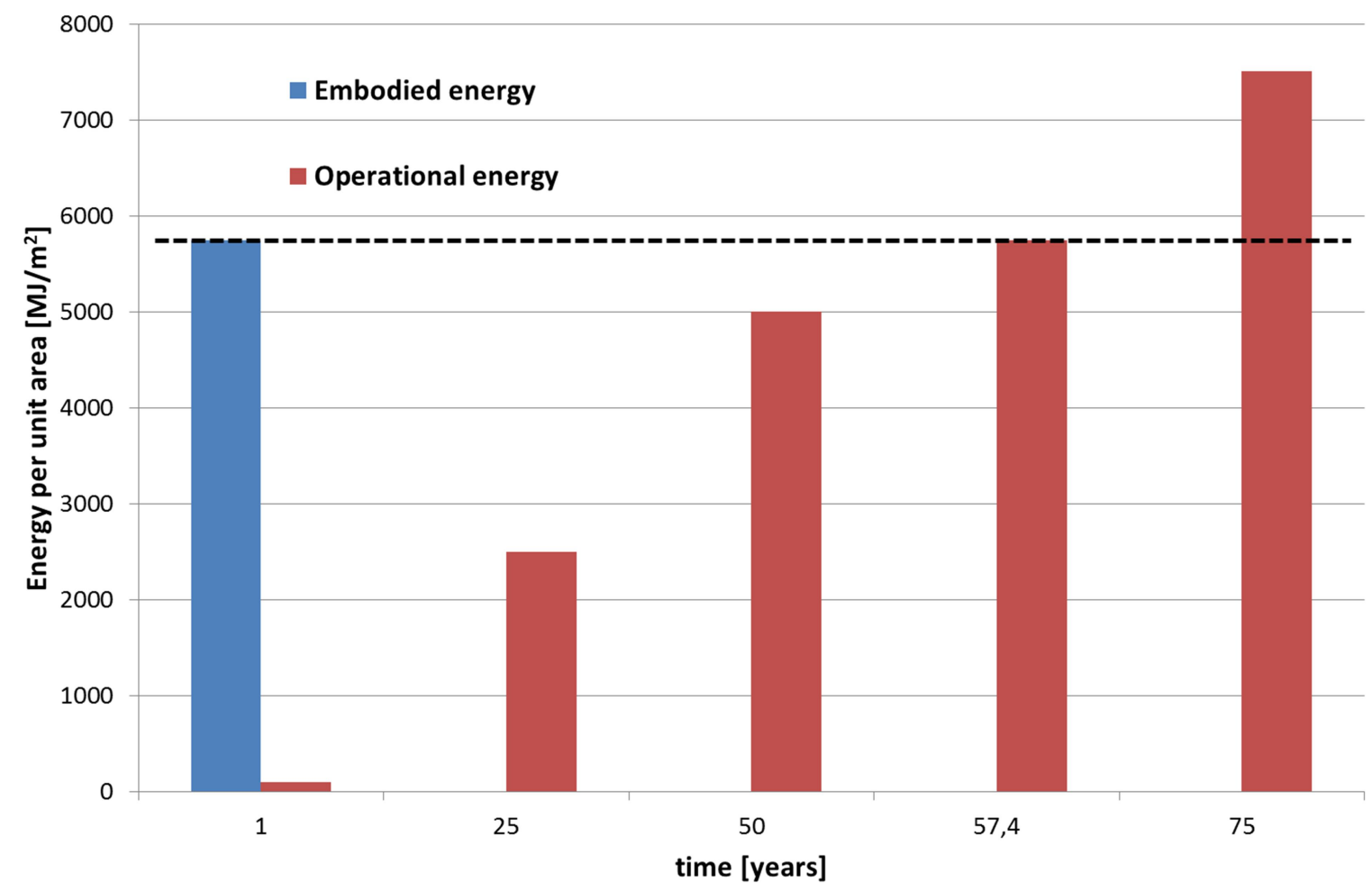

Figure 4. Embodied energy and operational energy at different years.

\section{Energy retrofit strategies}

The aim of this step is to highlight the solutions able to reduce the operational energy for heating and cooling of the typical hall. 
The proposed intervention strategies were chosen in relation to the particular kind of building and to the real feasibility. They are grouped into interventions at the envelope level and interventions at the HVAC system management level.

The solutions regarding the energy performance of the envelope are:

1. internal insulation of the vertical panels, adopting $13 \mathrm{~cm}$ of rock wool, so that thermal transmittance passes from the present value $\mathrm{U}=1.87 \mathrm{~W} /\left(\mathrm{m}^{2} \mathrm{~K}\right)$ to $\mathrm{U}^{\prime}=0.25 \mathrm{~W} /\left(\mathrm{m}^{2} \mathrm{~K}\right)$;

2. external insulation of the vertical panels, adopting $13 \mathrm{~cm}$ of rock wool, passing from $\mathrm{U}=1.87$ $\mathrm{W} /\left(\mathrm{m}^{2} \mathrm{~K}\right)$ to $\mathrm{U}^{\prime}=0.25 \mathrm{~W} /\left(\mathrm{m}^{2} \mathrm{~K}\right)$;

3. roof insulation, combining $5 \mathrm{~cm}$ of glass wool and $17 \mathrm{~cm}$ of EPS, passing thus from $\mathrm{U}=0.27$ $\mathrm{W} /\left(\mathrm{m}^{2} \mathrm{~K}\right)$ to $\mathrm{U}^{\prime}=0.10 \mathrm{~W} /\left(\mathrm{m}^{2} \mathrm{~K}\right)$;

4. floor insulation, adding $12 \mathrm{~cm}$ of EPS, and passing from $\mathrm{U}=1.26 \mathrm{~W} /\left(\mathrm{m}^{2} \mathrm{~K}\right)$ to $\mathrm{U}^{\prime}=0.26$ $\mathrm{W} /\left(\mathrm{m}^{2} \mathrm{~K}\right)$;

5. clear painting of the roof, so that the albedo passes from $\mathrm{A}=0.5$ to $\mathrm{A}^{\prime}=0.9$;

6. clear painting of the vertical panels, changing the albedo from $\mathrm{A}=0.5$ to $\mathrm{A}^{\prime}=0.9$.

The interventions at the system management level are instead:

7. summer night ventilation (free cooling);

8. variation of the set point temperature (passing from $21^{\circ} \mathrm{C}$ to $20^{\circ} \mathrm{C}$ in winter, and from $23^{\circ} \mathrm{C}$ to $24^{\circ} \mathrm{C}$ in summer);

9. early switch off of the system (1 hour in advance).

Each intervention was simulated in EnergyPlus and the corresponding operational energy of the exhibition hall was compared with the reference operational energy based on the present envelope and system conditions.

\subsection{Energy savings in the use phase}

Considering firstly the energy saving due to strategies at the envelope level, the results of the dynamic simulations are shown in Figure 5.

Roof and walls insulation lead to a significant primary energy saving during the year, between 5.5\% and $6.4 \%$. In the case of the walls insulation the yearly energy saving results from a balance between a decrease of the heating demand and an increase of the cooling demand. The roof insulation instead results in a saving on both the heating and cooling energy.

Otherwise it is interesting to notice that reducing the floor thermal transmittance, by adding an insulation layer on the inside, leads to an increase in the primary energy consumption equal to $3.4 \%$, resulting for both an increase in winter and in summer, since it decreases also the floor thermal inertia. Since in this kind of buildings during the day important internal gains are produced, the floor thermal inertia helps using these gains to reduce the heating energy demand in winter and to attenuate the cooling load in summer. Finally increasing the albedo of the roof and of the walls has a negative impact on the primary energy consumption, since the reduction in the cooling energy does not overcome the increase in the heating energy. 


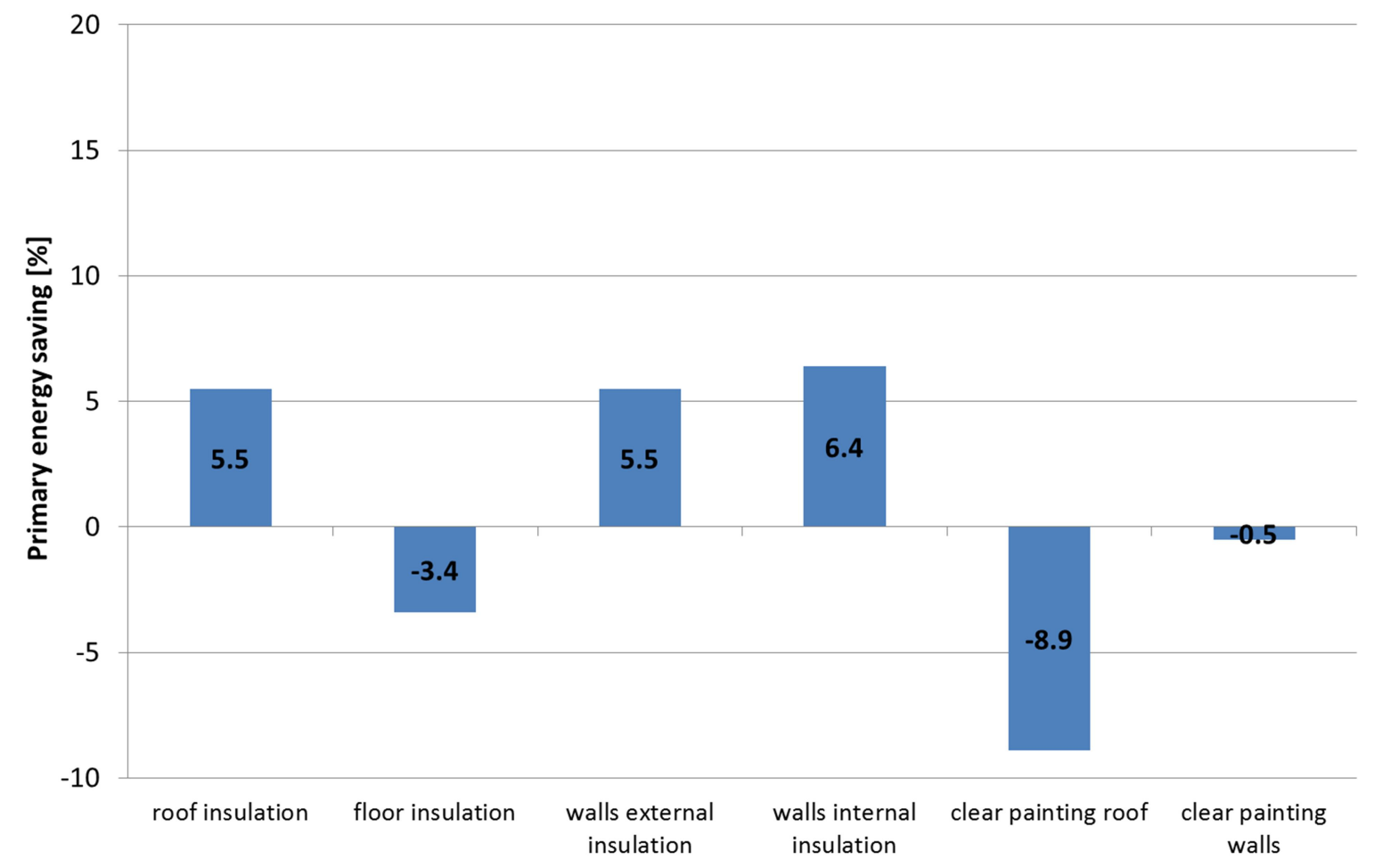

Figure 5. Energy savings due to retrofit interventions on the envelope.

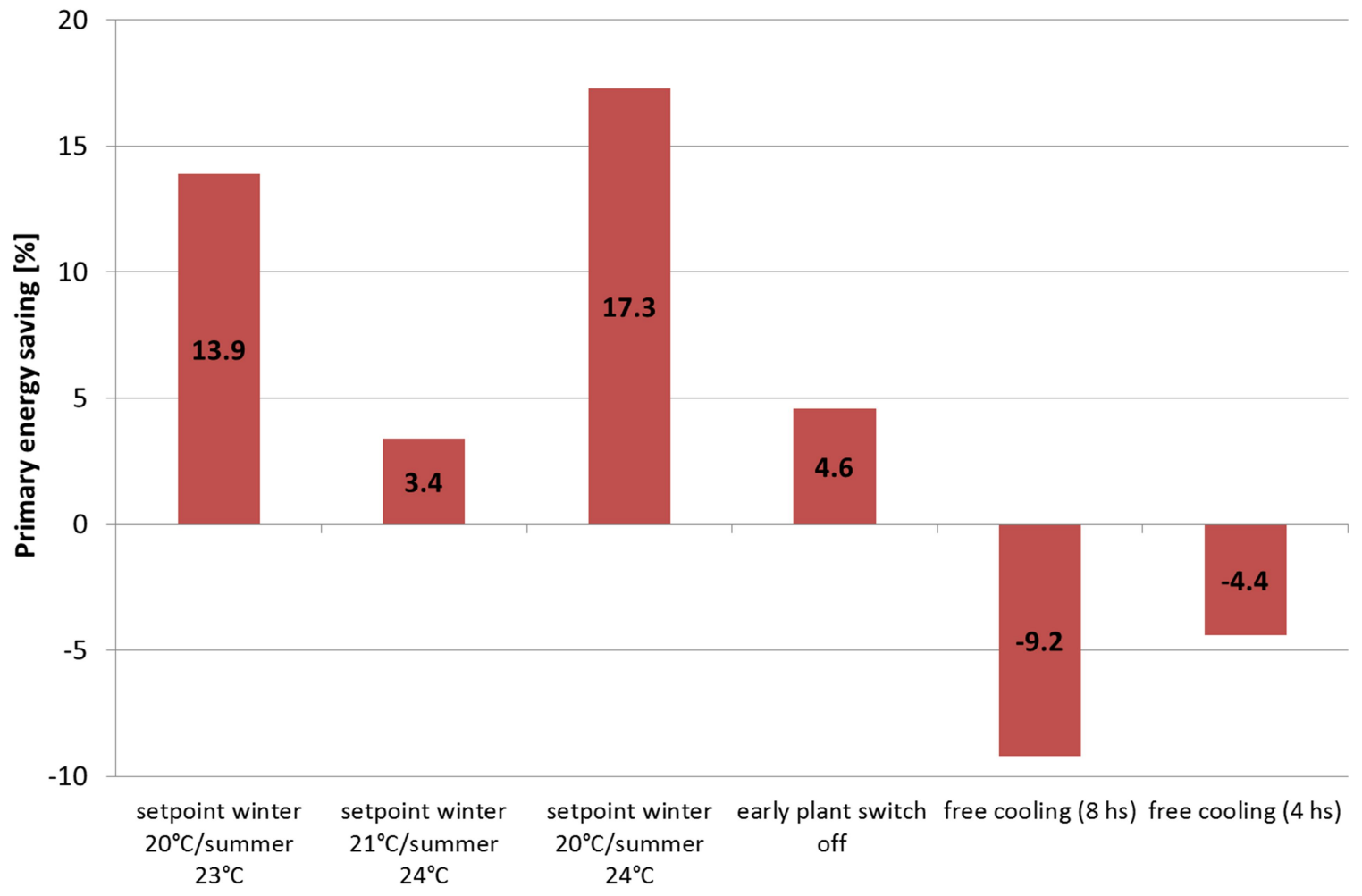

Figure 6. Energy savings due to HVAC systems management strategies. 
The energy savings due to intervention at the system management level are shown in Figure 6. Among the system management strategies, the variation of the setpoint temperature leads to an important energy saving, up to $17 \%$ if both the winter and the summer setpoints are modified by only $1^{\circ} \mathrm{C}$.

Another strategy that leads to an energy saving of about 5\% regards the possibility to switch off the plant one hour before the closing of the event. In this case it was verified that in the $98 \%$ of the time the temperature maintains an acceptable value (the difference between the indoor temperature and the setpoint value is lower than $2^{\circ} \mathrm{C}$ ).

Adopting a free cooling strategy in summer events, through mechanical ventilation eight hours per night, would reduce the electricity consumption for cooling. However the increase in the electricity consumption of the presently installed fans overcomes the savings, so that this strategy is not advantageous, also considering only four hours of free cooling per night.

After simulating individual solutions, the most promising individual solutions were combined. As it is shown in Figure 7, combining roof insulation, walls insulation, the variation of the setpoint temperature and the early plant switch off, an annual saving of $31.5 \%$ can be achieved.



Figure 7. Energy savings for combined interventions. 


\subsection{Economic assessment: PayBack Time, Discounted PayBack Time, Net present Value and Internal Rate of Return}

At this stage are the estimated simple PayBack Time (PBT), the Discounted PayBack Time (DPBT), the Net Present Value (NPV) and the Internal Rate of Return (IRR) for the retrofit strategies regarding envelope components, namely 1,2 and 3 in the list in paragraph 6 . The traditional PBT assessment (refurbishment cost/annual saving) has been integrated with the DPBT in order to take into account the present value - i.e. the actual value of an amount of money that will be received in the future - of the expected savings over time: The economic assessment has been completed with the use of other two methods, i.e. NPV and IRR, that are more reliable in representing the opportunity to invest in energy saving retrofit (Busato et al. 2008).

Regarding internal insulation on the walls, by considering the price list for the execution of public works and maintenance (Regione Lombardia 2009) and the price list of public works and the structural characteristics of the market for public works (Comune di Milano 2010), the original investment was estimated in $235,303 €$. Considering a cost of $0.05 € / \mathrm{kWh}$ and of $0.11 € / \mathrm{kWh}$, that corresponds to the present costs for the heating and electricity supply of the Milan Trade Fair, it is possible to get an annual saving of $1,343 €$, that is clearly too small compared to the initial investment, resulting in a PBT of about 175 years. The DPBT is normally longer then PBT so it has not been considered interesting to calculate it. This outcome is due on the one side to the low cost of the heating supply by the Waste-To-Heat Municipal Plant, and on the other side mainly to the short use period of the exhibition hall, that is only 52 days per year. Actually if the hall was used as a common office/commercial building (5 days a week), the annual saving would be $6,716 €$, with a PBT of about 35 years. Considering also the deduction of 55\% (Decree 2008/03/11, Decree 2008/04/07) the PBT would reduce to about 16 years. In this case, considering a discount factor of $3 \%$ (Lavappa and Kneifel 2016), a yearly increase of the energy cost at $4 \%$ and the tax saving of $55 \%$ allowed by law, the DPBT would be 17 years.

The calculation of NPV and IRR has been done - for the scenario of 5 days per week use of the building - assuming a life cycle of 25 years and a discount factor of 3\%. The energy cost was kept constant in one simulation and increasing with a constant yearly rate of $4 \%$ in a second simulation. The results of the assessment show a negative NPV of $-€ 114,909.03$ (constant energy cost) and $-€$ $43,174.63$ (increasing energy cost), a negative IRR of $-2 \%$ (constant energy cost) and a (positive IRR equal to $+1 \%$ (increasing energy cost).

Furthermore the impact of the uncertainty of the discount factor (DF) has been assessed. Discount factor may vary over time and is affected by the cost of equity and the cost of debt for the organization (Fujita 2016). The above mentioned cost categories depend on the risk associated to the organization activities and to the Country in which the organization is based (Stephan and Stephan 2014). In order to evaluate the impact of the discount factor variability on the economic assessment of the retrofit works, different discount factors have been considered according to those applied in the evaluation of the energy efficiency policy framework in the EU (Steinbach and Staniaszek 2015) for tertiary buildings, included in a range from $4,7 \%$ to $5,4 \%$. As expected, the results showed in Table 5 confirm the negative influence of the increase in the discount factor in the NPV due to the lowering of the future cash flows that are discounted with a higher value. This behavior leads to an application of the LCC models according to different strategies in relation with the overall aims of the users: "social discount rates", that do not include risk factors, are normally 
considered for assessment from a societal perspective and "individual discount rates" may be applied for decision making purposes by the investor (Steinbach and Staniaszek 2015).

Following the same approach, the economic assessment was applied also to the retrofit interventions regarding the insulation of the walls from the outside and the roof insulation. The results, summarized in Table 5, show that the low-intensity use of the exhibition hall dramatically influences the economic feasibility evaluation of any intervention related to envelope components.

Table 5. Economic assessment of some retrofit interventions

\begin{tabular}{|c|c|c|c|c|}
\hline & & $\begin{array}{c}\text { Walls internal } \\
\text { insulation }\end{array}$ & $\begin{array}{c}\text { Walls external } \\
\text { insulation }\end{array}$ & Roof insulation \\
\hline Cost (€) & & 253,303 & 235,303 & $2,091,420$ \\
\hline \multirow{2}{*}{$\begin{array}{l}\text { Annual } \\
(€ / \mathbf{a})\end{array}$} & Low intensity use & 1,343 & 1,147 & 1,197 \\
\hline & Typical use & 6,716 & 5,735 & 6,000 \\
\hline \multirow[t]{2}{*}{ PBT (a) } & Low intensity use & 175 & 205 & - \\
\hline & Typical use (+tax breaks) & $35(16)$ & $41(18)$ & $-(130)$ \\
\hline \multirow[t]{2}{*}{ DPBT (a) } & Low intensity use & - & - & - \\
\hline & Typical use (+tax breaks) & 17 & 20 & - \\
\hline \multirow[t]{4}{*}{ NPV (€) } & $\begin{array}{lll}\text { Constant } & \text { energy } & \text { cost } \\
(\mathrm{DF}=3 \%) & & \end{array}$ & $-114,909$ & $-131,494$ & $-1,929,069$ \\
\hline & Increasing energy cost & $-43,175$ & $-70,238$ & $-1,864,982$ \\
\hline & $\begin{array}{lll}\begin{array}{l}\text { Constant } \\
(\mathrm{DF}=4.7 \%)\end{array} & \text { energy cost } \\
\end{array}$ & $-131,552$ & $-145,164$ & - \\
\hline & $\begin{array}{lll}\begin{array}{l}\text { Constant } \\
(\mathrm{DF}=5,4 \%)\end{array} & \text { energy } & \text { cost } \\
\end{array}$ & $-136,934$ & $-149,542$ & - \\
\hline \multirow[t]{2}{*}{ IRR (\%) } & $\begin{array}{l}\text { Constant energy cost } \\
(+ \text { tax breaks })\end{array}$ & $-2 \%(+2.58 \%)$ & $-3 \%(+1.6 \%)$ & $-15 \%(-)$ \\
\hline & $\begin{array}{l}\text { Increasing energy cost } \\
(+ \text { tax breaks })\end{array}$ & $+1 \%(+5.6 \%)$ & $0 \%(+4.6 \%)$ & $-11 \%(-)$ \\
\hline
\end{tabular}

\subsection{Calculation of the embodied energy of the retrofit strategies}

The aim of this paragraph is the evaluation of the embodied energy of the added materials related to the energy retrofit strategies on the envelope whose economic assessment has been illustrated in the previous paragraph. As reported in section 6, for the walls insulation $13 \mathrm{~cm}$ of rock wool are used, while for the roof insulation both EPS and glass wool are employed for an overall thickness of 22 $\mathrm{cm}$.

Table 6 is a summary of the embodied energy (Primary Energy or PEI) of the added materials of the retrofit strategies. All the data concerning the embodied energy (the renewable and non-renewable Primary Energy consumption of the pre-production and production phases, namely PEI ren and PEI non-ren) have been taken from the EPD (Environmental Product Declaration) of each material. The choice to take the data from EPD is driven by the fact that data are more reliable than those of a generic database.

Table 6. The embodied energy of the materials of the retrofit strategies.

PEI of the material $(\mathrm{MJ} / \mathrm{Kg})$

PEI of added materials for retrofit (MJ)

\begin{tabular}{cccccc}
\hline EPS & Glass wool & Rock wool & $\begin{array}{c}\text { Roof } \\
\text { EPS }\end{array}$ & $\begin{array}{c}\text { Roof } \\
\text { Glass wool }\end{array}$ & $\begin{array}{c}\text { Int/Ext } \\
\text { Rock wool }\end{array}$ \\
\hline
\end{tabular}




\begin{tabular}{ccccccc}
\hline ren & 1.8 & 1.3 & 0.1 & 194,177 & 243,357 & 4,337 \\
\hline non-ren & 110.7 & 28.8 & 12.9 & $11,941,911$ & $5,223,104$ & 559,454 \\
\hline total & 112.5 & 30.1 & 13.0 & $12,136,088$ & $5,466,461$ & 563,791 \\
\hline
\end{tabular}

Another very important issue concerns the transport, whose impacts are not negligible. The designer can choose between a high variety of materials from all over the world thanks to globalization of markets favored by the economy and ease of transport. In this analysis, having considered the EPD values "from cradle to gate" of each materials, primary energy consumptions related to the transport to the place of production are already included; only the primary energy consumptions for the transport of materials from the factory to the building site are calculated and added.

The factories closer to the building site for each kind of material have been assumed, with the aim of reducing embodied energy: $172 \mathrm{~km}$ for EPS, $63 \mathrm{~km}$ for glass wool and $520 \mathrm{~km}$ for rock wool.

After the identification of the factories closer to the building site for each material, the calculation of the indicator "tkm" (ton per kilometer) was carried out. Afterwards, it has been hypothesized a transport by truck to the building site considering the primary energy consumption of a medium truck (32 t) per $1 \mathrm{tkm}$ (see Table 7).

Table 7. Embodied energy due to the transport by truck from gate to building site.

Embodied energy due to transport by truck

\begin{tabular}{lcccc}
\cline { 2 - 5 } Indicator & 1 truck (32t) per 1tkm & EPS & Glass wool & Rock wool \\
& 3.71 & 68,857 & 42,459 & 83,689 \\
\hline PEI non-ren (MJ) & 0.06 & 1,039 & 641 & 1,263 \\
\hline PEI ren (MJ) & 3.77 & 69,896 & 43,100 & 84,952 \\
\hline PEI tot (MJ) & & & & \\
\hline
\end{tabular}

Overall, considering the embodied energy due to materials (Table 6) and due to transport (Table 7), the retrofit strategies internal/external insulation with rock wool have the lower embodied energy, despite the significant impacts of transport. Therefore, considering that the energy savings in the use phase of the three retrofit strategies are similar (Figure 5), internal/external insulation with rock wool can be considered the most eco-efficient retrofit strategy.

\subsection{Comparison between the embodied energy of the retrofit strategies and the energy savings in the use phase}

The comparison between the energy consumption of the retrofit strategies during the pre-use phases (embodied energy in the pre-production and production and energy for transport) and the corresponding energy savings in the use phase was finally carried out.

The end of life was neglected because of the multiple scenarios that could be outlined.

This comparison allows to calculate the Energy PayBack Time for each refurbishment, namely the time when the energy spent in the refurbishment phase is compensated by the energy savings in the use phase.

Different scenarios regarding the service life of the interventions were proposed and for each of them energy consumptions (embodied energy + energy due to transport) and energy savings in the 
use phase were calculated. The results, expressed in energy per unit plan area of the building, are shown in Figure 8, Figure 9 and Figure 10 for walls internal insulation, walls external insulation and roof insulation respectively. In Figure 8, Figure 9 and Figure 10 at the first year the sum (embodied energy + energy due to transport) and the energy savings are shown. In the next years the cumulated energy savings are shown. Horizontal lines corresponding to the sum of the embodied energy and energy due to transport level are drawn, in order to facilitate detecting the Energy Payback Time.

Summarizing, considering the internal and external insulation it is possible to state that there is a significant decrease of the thermal transmittance (from $1.87 \mathrm{~W} /\left(\mathrm{m}^{2} \mathrm{~K}\right)$ to $0.24 \mathrm{~W} /\left(\mathrm{m}^{2} \mathrm{~K}\right)$ ) with 0.13 $\mathrm{m}$ of insulation material, while, considering the roof, there is a less relevant reduction of the thermal transmittance (from $0.27 \mathrm{~W} /\left(\mathrm{m}^{2} \mathrm{~K}\right.$ ) to $0.10 \mathrm{~W} /\left(\mathrm{m}^{2} \mathrm{~K}\right)$ ) despite the thickness of the material is considerably greater $(0.22 \mathrm{~m})$. Moreover it is important to notice that insulating the roof requires 7 times the amount of material than insulating the vertical panels $(290,000 \mathrm{~kg}$ for the roof and 43,000 $\mathrm{kg}$ for the wall), mainly due to the extension of the area involved $\left(36,300 \mathrm{~m}^{2}\right.$ of the roof and 3,700 $\mathrm{m}^{2}$ of the walls). This is the reason why the Energy PayBack Time for walls insulation, either internal or external, is significantly lower (approximately 3 years, Figure 8 and Figure 9) than for the roof insulation (more than 90 years, Figure 10). No recurring energy related to the replacement of insulation during the life cycle has been considered because in this case it would not change the identification of the best retrofit strategies. In literature there are variable replacement factors for insulation materials; if we consider an average period of 25 years, the Energy PayBack Time for walls insulation is still the best retrofit strategy.

Further it can be noticed that the Economic PayBack Times (Errore. L'origine riferimento non è stata trovata.) are generally much larger than the Energy PayBack Time calculated here. The low cost of the heating energy and electricity achieved by the Milan Trade Fair contributes to this large difference, but it is clearly not enough. The retrofit intervention on the walls that is paid back in very long times on an economic basis are rather affordable on a primary energy basis, considering the low quantity of material related to the significant reduction of the thermal transmittance (and then of the energy consumption). 


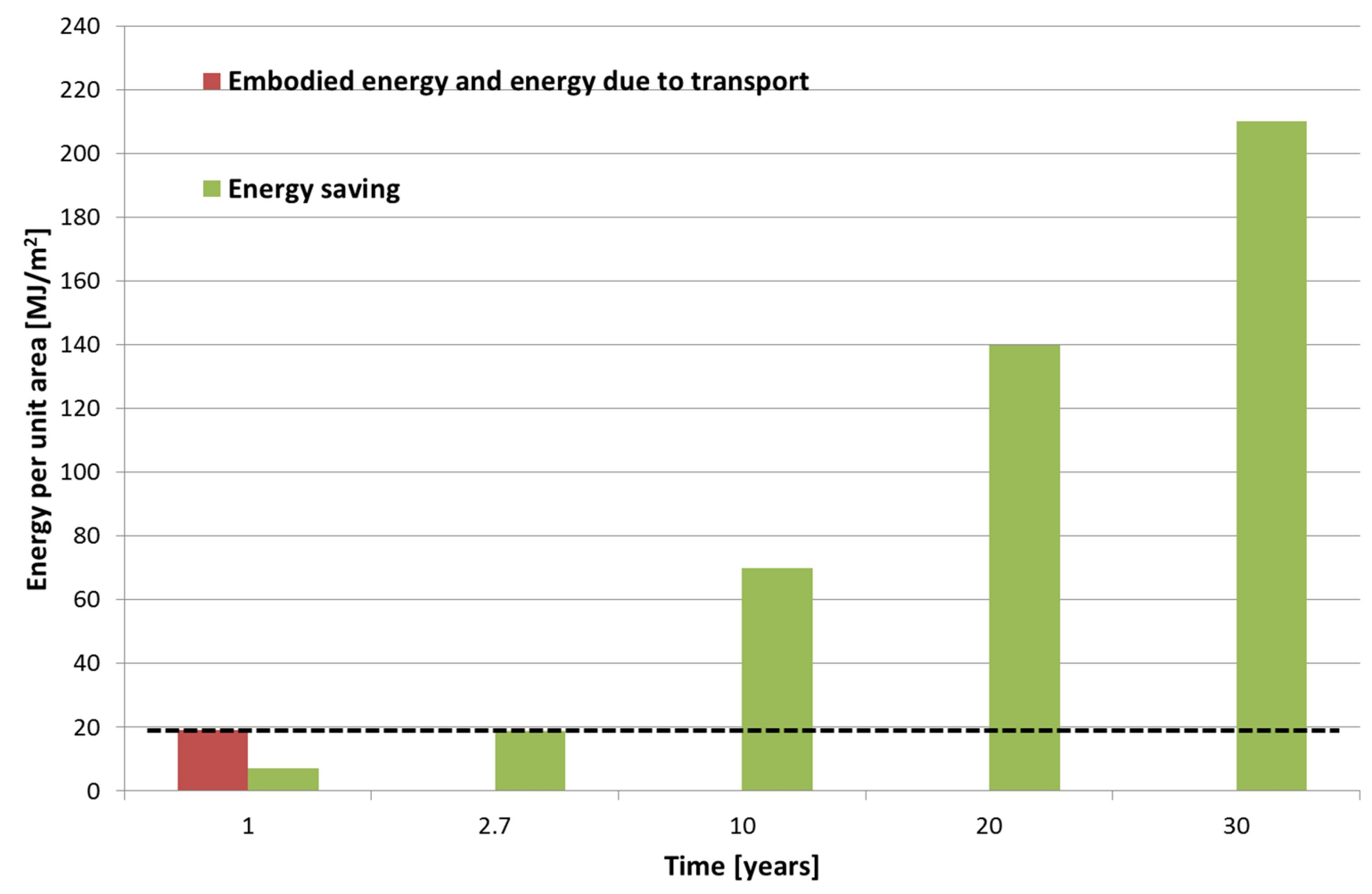

Figure 8. The Energy PayBack Time of the walls internal insulation.

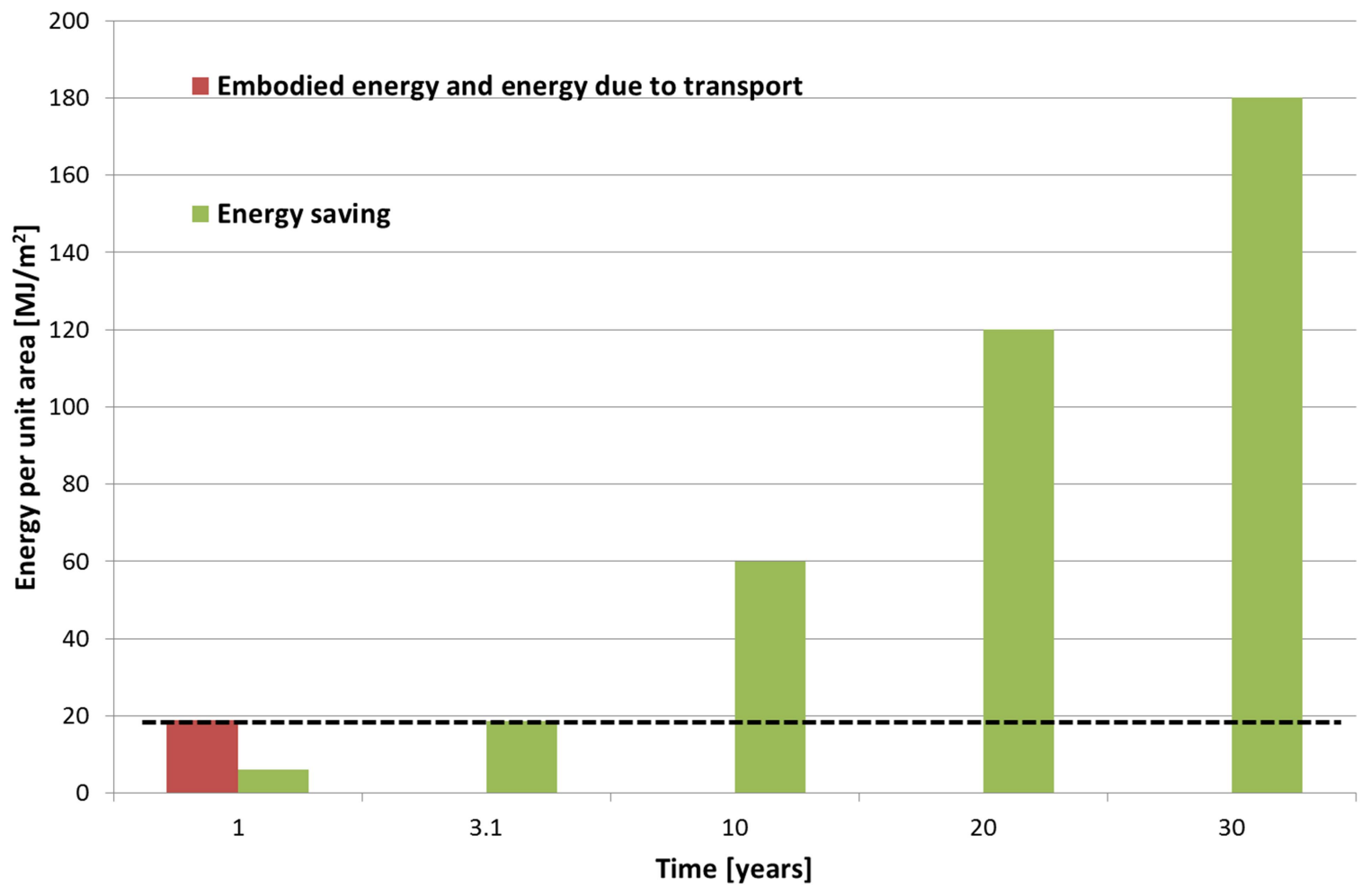

Figure 9. The Energy PayBack Time of the walls external insulation. 




Figure 10. The Energy PayBack Time of the insulated roof.

\section{Critical issues of the evaluation}

LCEA is a quantitative evaluation that allows an objective check, even though the reference to numerical values is not synonymous with reliability and all the assessments (especially with the degree of reliability of data now available) may have a margin of uncertainty. Information arising from the LCEA are used to define guidelines and allow to redirect wrong strategies.

Undertaking an evaluation of buildings or materials in the life cycle should be the current and future focus, even if LCEA is a complex methodology and there are many uncertainties and limitations in current practices. It is not always easy to get reliable data and enough information for all the life cycle processes, so generally during the process of design choice simplified LCEA is used. But the variability of the data may also lead to changes in the final evaluation (Lavagna 2008). For this reason, in this study, the impact of some choices was analyzed in order to verify the robustness of results.

Following are some of the main critical issues of the LCEA that emerge by this study.

\subsection{Implications of different life cycle inventory methods on LCEA results}

Life cycle assessments (LCA) and environmentally extended input-output (EEIO) analyses both strive to account for direct and indirect environmental impacts of goods and services. Though the LCA data was more detailed overall, some sectors of the economy were more precisely represented in the EEIO database (Majeau-Bettez et al. 2011). 
The embodied energy values adopted in this study rely on the so-called process-based analysis to quantify environmental impacts, including energy consumption. This is the most used life cycle inventory method, according to the technical standards related to sustainability of buildings, ISO 21929-1 (2011) and EN 15643-2 (2011), that are in compliance with LCA methodology (ISO 14040:2006).

But some authors highlight that conventional process-analysis-type techniques for compiling lifecycle inventories suffer from the so-called "truncation error" which is caused by the omission of resource requirements or pollutant releases of higher-order upstream stages of the production process; the magnitude of this truncation error varies with the type of product or process considered, but can be on the order of 50\% (Lenzen 2000) up to 87\% (Crawford 2008).

The use of input-output data assists in improving the system boundary completeness of life-cycle inventories. However, the use of input-output analysis alone does not always provide an accurate model for replacing process data. More recently, hybrid inventory analysis methods have been developed, combining these two traditional methods in an attempt to minimise their limitations.

For instance, Crawford (2011) has shown that input-output-based hybrid analysis can produce embodied energy figures up to $\sim 4$ times higher than process analysis, for the same building.

Therefore, the absolute value of embodied energy associated with materials in this study can be underestimated. Anyway, even if the embodied energy of insulation would be 4 times higher, the walls insulation would remain the most energy-efficient retrofit strategy.

\subsection{Influence of the embodied energy databases}

One of the main issue of LCEA is how to collect the appropriate data (representative technologies, geographical context, energy mix, life cycle phases and elements included and system boundaries analyzed).

In particular, considering the embodied energy of the materials such as in the previous analysis, it is possible to have different values depending on the database: it is difficult to understand how the data were built in the different databases, how to compare them, which phases have been considered and which processes are included (for example it is often difficult to understand if packaging is included or not). EPD (Environmental Product Declaration) can be the solution for affordable data, but it is not mandatory and widely diffuse.

Figure 11 shows the embodied energy per unit mass of EPS, glass wool and rock wool considering different sources, showing that the choice of the type of data is critical in a LCEA analysis. 


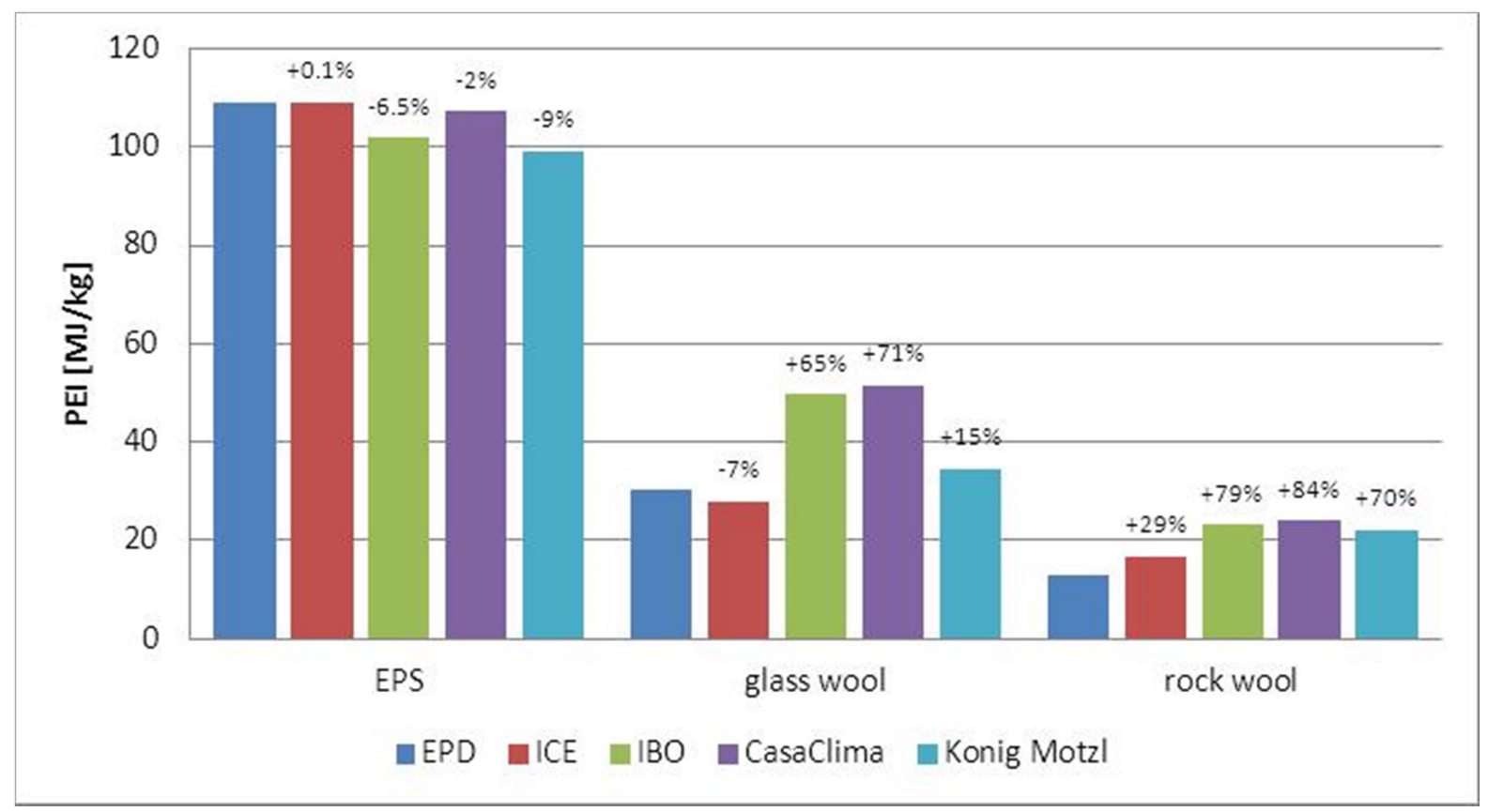

Figure 11. Embodied energy per unit mass of the insulating materials considering different sources (Lavagna et al. 2011): EPD of a specific products, ICE (Inventory of Carbon and Energy edited by the University of Bath, 2011), IBO (Austrian Institute for Healthy and Ecological Building, 2005), Casaclima, studies of single authors (Holger Konig, 2000; Hildegund Motzl, 2000).

Depending on the type of study, either detailed or simplified, it should be chosen whether to use secondary data from the database or primary data collected in relation to a specific product. Even in case of collection of primary data, it is necessary to define if they are collected only for the main processes or also for the entire production chain. In this analysis, as already mentioned, data taken from EPD were chosen because specific retrofit solutions have been hypothesized. As Figure 11 shows, the assessments may change greatly if data from other sources have been taken. In this study, the use of EPD data ensures the reliability of the results.

The debate on the reliability of the databases to process LCEA remains open, above all the issue about exporting data from a specific context to another. It would be appropriate that the designer requires the EPD of the materials, so that the companies would be encouraged to draw it: in this way the comparisons between materials would be easier and more reliable.

\subsection{Role of the transportation}

The energy consumption due to the transport of building materials and components from the factory to the site is not negligible. However, it is difficult to control and calculate all the energy consumption due to transport during the design phase, also because the designer provides the technical specifications for products but he does not address the choice of suppliers, which is a task of the construction company.

Two important considerations have to be taken into account: the transportation system and the location of the factory of the chosen material. Here the transportation system variability will be considered.

Currently, road transport is often chosen because it allows to achieve decentralized locations, where the plants are usually located, with a unique means of transport. But road transport is significantly 
more impacting than the transportation, with a ratio about 1:6 (Figure 12), considering direct (fuel) and indirect (vehicles and infrastructure) energy consumption.

In the calculation of the embodied energy of the retrofit interventions in paragraph 6.3 road transport was assumed (Table 7). Here a transport by train to the building site is also considered: the energy consumption of the transport considering $1 \mathrm{tkm}$ has been multiplied for the total $\mathrm{tkm}$ of each material (related to the retrofit strategies). Comparing the energy consumption of the two transportation systems (see Figure 12), it is evident that the rail transport is more advantageous. However in this study the choice of the transportation system does not affect significantly the final picture, with reference to the remarks in paragraph 6.4. In this case study the embodied energy due to transport related to the roof materials is negligible; the embodied energy due to transport related to the walls influences for a $15 \%$ and for a $2 \%$ the total embodied energy if the transport is by truck or by train respectively.



Figure 12. Comparison between the energy consumption due to transport by truck and by train (source of LCEA data for 1tkm: Ecoinvent).

In general, the environmental assessment tools and the environmental criteria for sustainable design (in Green Public Procurement and in Green Building Rating Systems) promote the choice of local materials to reduce impacts due to transport. The purchase of products is often done by local dealers that, however, can supply very far away. Furthermore, the products can come from plants that produced the finished component, assembling or operating the latest process, but the network of the suppliers of the materials and semi-finished products that are needed to produce the finished component can be articulated and the material can come from far away. Consequently the local origin should be demonstrated throughout the supply chain and not only in the last steps; this demonstration is often very difficult because of the paucity of information available from producers. Finally it should be emphasized that the local origin is not synonymous with reduction of energy consumption in absolute terms because the energy consumption is related also to the weight of the 
materials and the dimensions of transport. For example it may be more advantageous a product with enhanced modes of transport (compressed load) from a distant factory rather than a product with non-optimized mode of transport coming from a near factory. These considerations demonstrate once again the need for an energy balance in the life cycle linked to the specific case, that allows to compare alternatives in relation to real amount of material to be transported, weight, compact dimensions, distances and means of transport.

It would be desirable that the designer puts limits and conditions on the origin of materials in order to be able to manage and reduce the energy consumption in this field. This would also greatly influence the actions of the companies, which would have an incentive to structure and make transparent all the information about the energy consumption of all the phases of the construction process, also related to transport.

\subsection{Variability of the insulation materials profile}

When comparing and evaluating different materials, it is important to take into account the performance required. For example, if a comparative evaluation of insulating materials has to be set, the performance of thermal insulation is achieved by a number of different products depending on the thermal conductivity of different materials with different density so the comparison should not be at the same weight but at the same performance. For this reason it becomes necessary to clarify the expected performance of the products and the functional unit, in order to calculate the related reference flow (quantity of material).

Following, an example of comparative analysis of different types of insulation is shown, considering the thermal transmittance as functional unit, for the internal insulation case.

In Figure 13 the different values of thickness of the insulations, apart from the rock wool chosen adopted in paragraph 6.3, allowing to achieve the set thermal transmittance in the case of internal insulation retrofit strategy are shown.

As already mentioned, considering the thermal transmittance as functional unit, the amount of materials changes (related also to density) and, if it happened, also the impacts due to transport would change and so on: all the aspects of uncertainty and all the variables depend on each other.

The total mass of each material was then calculated in order to compare the differences in terms of embodied energy (see again Figure 13) of the internal insulations retrofit strategy.

It has to be noted that also considering the same material, different density values (related to different products and producers) and also different values of embodied energy per unit mass (related to different databases or EPD) can be found, increasing the variability of the analysis. In this comparison the values of embodied energy per kilogram were taken by the database ICE (Hammond and Jones 2011).

Results in Figure 13 show that the choice of the material can greatly change the result, up to six times if we compare cork and cellular glass. However in this study, the difference of the embodied energy of the different retrofit strategies is much higher than six times. Hence, even by changing the materials, the walls insulation would remain the most energy-efficient retrofit strategy. 


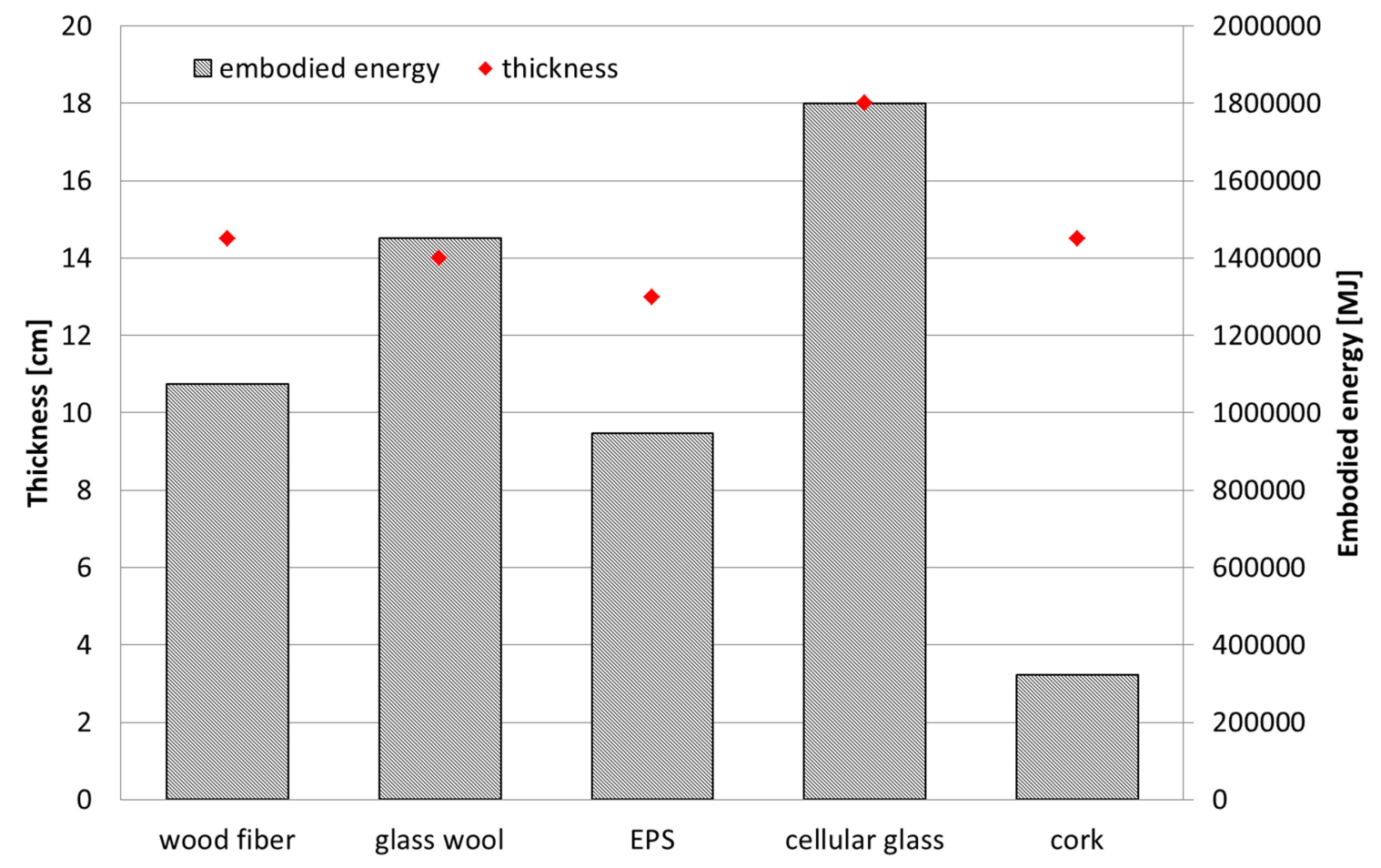

Figure 13. Different insulations thickness to achieve the set thermal transmittance and corresponding embodied energy.

\section{Conclusions and discussion}

A literature review on Life Cycle Energy Analysis has put in evidence that most studies focus on residential and office buildings. In this paper for the first time to the best of the authors' knowledge a comprehensive energy analysis of a peculiar kind of building, namely an exhibition hall of a trade fair centre, was carried out. The analysis included the assessment of both the operational energy for climatisation and the embodied energy of the building envelope and structure.

Although the building envelope is not especially efficient from an energy perspective, an artificially low value of the operational energy for climatisation was found, due to the small effective use period during the year. This result may occur also in other kinds of buildings with a low-intensity use. The exhibition hall embodied energy, when represented per unit volume rather than per unit area, appears comparable with literature data, although they mostly refer to residential buildings that are only partially comparable with the case study. More efforts are needed to produce reference embodied energy figures for building typologies different from residential ones. The absence of internal partitions and slabs in the exhibition hall determines a relatively low use of construction materials compared to residential buildings and thus influences the final embodied energy figure of the hall. This result may occur in general in any hall, namely in any building being a large single volume. In the comparison between embodied energy and operational energy of the hall, again the role of the short use period during the year was highlighted. 57 years are needed for the operational energy to balance the embodied energy, but they would reduce to less than 8 years if the exhibition hall yearly use were similar to an office. 
As a second step, an energy analysis of some energy retrofit interventions was carried out, both from the operational energy and from the embodied energy point of view. The most effective interventions at the envelope and HVAC systems management levels were identified. However, the retrofit interventions based on insulation resulted in quite long Economic PayBack Times, mainly due to the low-intensity use of the building. Therefore, on the operational energy basis, the only feasible interventions are the no cost ones, based on the HVAC management strategies. On the contrary, on the embodied energy basis, i.e. comparing the embodied energy of the insulation interventions with the energy savings in the use phase, interesting Energy PayBack Times were achieved: the embodied energy of the insulation walls strategy is offset in only three years by the energy savings during the operational energy.

This outcome puts in evidence the added value of the embodied energy evaluation, since in this case it may lead to a completely different decision on the opportunity to afford the insulation interventions.

At the same time, it is clear that increasing the effective use of the exhibition halls, by considering the possibility of adapting these spaces to different activities, such as sport events, theatre events or concerts, would make energy retrofit strategies more economically advantageous. Moreover, also considering the life cycle perspective, adapting a building to multiple functions reduces the need to build more buildings for the different functions, and this means the reduction of the total energy consumption.

\section{References}

Anderson, J.E., Wulfhorst, G., Lang, W., Energy analysis of the built environment-A review and outlook, Renewable and Sustainable Energy Reviews 44 (2015) 149-158.

Atmaca, A., Atmaca , N., Life cycle energy (LCEA) and carbon dioxide emissions (LCCO2A) assessment of two residential buildings in Gaziantep,Turkey, Energy and Buildings 102 (2015) $417-431$.

Blengini, G.A., Di Carlo, T., The changing role of life cycle phases, subsystems and materials in the LCA of low energy buildings, Energy and Buildings 42 (2010) 869-880.

Boyano, A., Hernandez, P., Wolf, O., Energy demands and potential savings in European office buildings: Case studies based on EnergyPlus simulations, Energy and Buildings 65 (2013) 19-28.

Busato, F., Castellotti, F., Lazzarin, R., Life cycle assessment and life cycle cost of buildings' insulation materials in Italy, International Journal of Low-Carbon Technologies 3/1 (2008) 44-58.

Buyle, M., Braet, J.,Audenaert, A., Life cycle assessment in the construction sector: A review, Renewable and Sustainable Energy Reviews 26 (2013) 379-388.

Cabeza, L.F., Rincón, L., Vilariño, V., Pérez, G., Castell, A., Life cycle assessment (LCA) and life cycle energy analysis (LCEA) of building sector: a review, Renewable and Sustainable Energy Reviews 29 (2014) 394-416. 
Chau, C.K., Leung, T.M., Ng, W.Y., A review on Life Cycle Assessment, Life Cycle Energy Assessment and Life Cycle Carbon Emissions Assessment on buildings, Applied Energy 143 (2015) 395-413.

Comune di Milano (2010), Listino dei prezzi per l'esecuzione di opere pubbliche e manutenzioni, Milano (in Italian).

Crawford, R. H., Validation of a hybrid life-cycle inventory analysis method, Journal of Environmental Management 88 (2008) 496-506.

Crawford, R. H., Life cycle assessment in the built environment, London, Spon Press, 2011.

Crawford, R.H., Bartak, E.L., Stephan, A., Jensen, C.A., Evaluating the life cycle energy benefits of energy efficiency regulations for buildings, Renewable and Sustainable Energy Reviews 63 (2016) $435-451$.

Crawley, D.B., Lawrie, L. K., Winkelmann, F. C.,Buhl, W.F., Huang, Y. J., Pedersen, C. O., Strand, R. K., Liesen, R.J., Fisher, D. E., Witte, M.J., Glazer, J., EnergyPlus: creating a newgeneration building energy simulation program, Energy and Buildings 33 (2001) 319-331.

Decree 2008/03/11, “Attuazione dell'articolo 1, comma 24, lettera a) della legge 24 dicembre 2007, n. 244, per la definizione dei valori limite di fabbisogno di energia primaria annuo e di trasmittanza termica ai fini dell'applicazione dei commi 344 e 345 dell'articolo 1 della legge 27 dicembre 2006, n. 296" (in Italian).

Decree 2008/04/24, "Disposizioni in materia di detrazione per le spese di riqualificazione energetica del patrimonio edilizio esistente, ai sensi dell'articolo 1, comma 349, della legge 27 dicembre 2006, n. 296 (GU del 24 Aprile 2008)". (in Italian)

Decreee 2015/06/26, “Applicazione delle metodologie di calcolo delle prestazioni energetiche e definizione delle prescrizioni e dei requisiti minimi degli edifici”. (in Italian)

DesignBuilder, User's manual, 2009.

Din, A., Brotas, L., Exploration of life cycle data calculation: Lessons from a Passivhaus case study, Energy and Buildings 118 (2016) 82-92.

Dodoo, A., Gustavsson, L., Sathre, R., Building energy-efficiency standards in a life cycle primary energy perspective, Energy and Buildings 43 (2011) 1589-1597.

European Standard 15643-2 (2011), Sustainability of construction works. Assessment of buildings. Part 2: Framework for the assessment of environmental performance. Brussels: European Committee for Standardization (CEN).

ENEA, Rapporto Annuale Efficienza energetica 2012, Roma, 2013. 
EnergyPlus, Input Output Reference-The Encyclopedic Reference to EnergyPlus Input and Output, 2009.

Fujita, K.S.,Commercial Discount Rate Estimation for Efficiency Standards Analysis/Report DEAC02-05CH1 1231, Lawrence Berkeley National Laboratory, (2016).

Fumo, N., Mago, P., Luck, R., Methodology to estimate building energy consumption using EnergyPlus Benchmark Models, Energy and Buildings 42 (2010) 2331-2337.

Ganassali, S., Lavagna, M., Campioli, A., LCA benchmarks in building's environmental certification systems, 41st IAHS World Congress, Sustainability and Innovation for the Future, 1316th September 2016, Albufeira, Algarve, Portugal.

Gustavsson, L.,Joelsson, A., Life cycle primary energy analysis of residential buildings, Energy and Buildings 42 (2010), 2010-2020.

Hammond, G., Jones, C., Inventory of Carbon and Energy (ICE), Version 2.0, Department of Mechanical Engineering, University of Bath, UK, 2011.

Heo, Y., Choudhary, R., Augenbroe, G.A.,Calibration of building energy models for retrofit analysis under uncertainty, Energy and Buildings 47 (2012) 550-560.

International Standard 14040 (2006) Environmental management - life cycle assessment - principles and framework. Geneva: International Organization for Standardization (ISO).

International Standard 21929-1 (2011), Sustainability in building construction. Sustainability indicators. Part 1: Framework for the development of indicators and a core set of indicators for building. Geneva: International Organization for Standardization (ISO).

ITC-CNR, Protocollo ITACA Marche. Manuale strumenti di calcolo, 2009.

Kim, D., Park, C., Difficulties and limitations in performance simulation of a double skin facade with EnergyPlus, Energy and Buildings 43 (2011) 3635-3645.

Lavagna, M., Life Cycle Assessment in edilizia. Progettare e costruire in una prospettiva di sostenibilità ambientale, Hoepli Editore, Milano, 2008.

Lavagna, M., Paleari, M., Mondini, D., Murature ad alte prestazioni. Valutazioni termiche, acustiche, ambientali ed economiche di soluzioni di involucro in laterizio, Maggioli Editore, Milano, 2011.

Lavappa, P.D., Kneifel, J.D.,Energy Price Indices and Discount Factors for Life-Cycle Cost Analysis - 2016, Annual Supplement to NIST Handbook 135, NISTIR 85-3273-31 (2016). 
Lenzen, M., Errors in Conventional and Input-Output-based Life-Cycle Inventories, Journal of Industrial Ecology 4 (2000) 127-148.

Lee, B., Trcka, M., Hensen, J.L.M., Embodied energy of building materials and green building rating systems - A case study for industrial halls, Sustainable Cities and Society 1 (2011) 67- 71.

Li, X., Wen, J., Review of building energy modeling for control and operation, Renewable and Sustainable Energy Reviews 37 (2014) 517-537.

Majeau-Bettez, G., Strømman, A.H., Hertwich, E.G., Evaluation of process- and input-output-based life cycle inventory data with regard to truncation and aggregation issues, Environmental Science \& Technology 45 (2011) 10170-7.

Mustafaraj, G., Marini, D., Costa, A., Keane, M., Model calibration for building energy efficiency simulation, Applied Energy 130 (2014) 72-85.

Nassiopoulosa, Kuate, R., Bourquin, F., Calibration of building thermal models using an optimal control approach, Energy and Buildings 76 (2014) 81-91.

Raftery, P., Keane, M., Costa, A., Calibrating whole building energy models: Detailed case study using hourly measured data, Energy and Buildings 43 (2011) 3666-3679.

Raftery, P., Keane, M., O’Donnell, J., Calibrating whole building energy models: An evidencebased methodology, Energy and Buildings 43 (2011) 2356-2364.

Ramesh, T., Prakash, R., Shukla, K.K., Life cycle energy analysis of buildings: an overview, Energy and Buildings 42 (2010) 1592-1600.

Regione Lombardia (2009), Prezziario delle opere pubbliche Regione Lombardia, Dei, Milano.

Ryan, E. M.,Sanquist, T.F., Validation of building energy modeling tools under idealized and realistic conditions, Energy and Buildings 47 (2012) 375-382.

Rossellò-Batle, B., Ribas, C., Moià-Pol, A. Martinez-Moll, V., An assessment of the relationship between embodied and energy demands in dwellings in a Mediterranean climate, Energy and Buildings 109 (2015) 230-244.

Sartori, I., Hestnes, A.G., Energy use in the life cycle of conventional and low-energy buildings: a review article, Energy and Buildings 39 (2007) 249-257.

Sharma, A., Saxena, A., Sethi, M., Shree, V., Life cycle assessment of buildings: a review, Renewable and Sustainable Energy Reviews 15 (2011) 871-875.

Slavković, K., Radivojević, A., Evaluation of energy embodied in the external wall of single-family buildings in the process of energy performance optimisation, Energy Efficiency 8 (2015) 239-253. 
Steinbach, J., Staniaszek, D., Discount rates in energy system analysis, Discussion Paper, Buildings Performance Institute Europe (BPIE), 2015.

Stephan, A., Crawford, R.H., de Myttenaere, K., A comprehensive assessment of the life cycle energy demand of passive houses, Applied Energy 112 (2013) 23-34.

Stephan, A., Stephan, L., Reducing the total life cycle energy demand of recent residential buildings in Lebanon, Energy 74 (2014) 618-637.

Szalay, A.Z.-Z., What is missing from the concept of the new European Building Directive?, Building and Environment 42 (2007) 1761-1769.

UNI 10351, Materiali da costruzione. Conduttività termica e permeabilità al vapore, Ente Nazionale di Unificazione, Milano, 1994. (in Italian)

UNI EN ISO 14683, Ponti termici in edilizia - Coefficiente di trasmissione termica lineica - Metodi semplificati e valori di riferimento, Ente Nazionale di Unificazione, Milano, 2001. (in Italian)

Weissenberger, M., Jensch, W., Lang, W., The convergence of life cycle assessment and nearly zero-energy buildings: The case of Germany, Energy and Buildings 76 (2014) 551-557. 